\title{
Achieving Net Zero Carbon Dioxide by Sequestering Biomass Carbon
}

\author{
Jeffrey A. Amelse 1,2 \\ 1 CICECO, Aveiro Institute of Materials, Department of Chemistry, University of Aveiro, 3810-193 \\ Aveiro, Portugal; JAmelse@UA.Pt; \\ 2 Independent Contributor, Batavia, IL 60510 USA; AmelseJeff@Gmail.com \\ Received: date; Accepted: date; Published: date
}

\begin{abstract}
Mitigation of global warming requires an understanding of where energy is produced and consumed, the magnitude of carbon dioxide generation, and proper understanding of the Carbon Cycle. The latter leads to the distinction between and need for both $\mathrm{CO}_{2}$ and biomass CARBON sequestration. Short reviews are provided for prior technologies proposed for reducing $\mathrm{CO}_{2}$ emissions from fossil fuels or substituting renewable energy, focusing on their limitations. None offer a complete solution. Of these, $\mathrm{CO}_{2}$ sequestration is poised to have the largest impact. We know how to do it. It will just cost money, and scale-up is a huge challenge. Few projects have been brought forward to semi-commercial scale. Transportation accounts for only about $30 \%$ of U.S. overall energy demand. Biofuels penetration remains small, and thus, they contribute a trivial amount of overall $\mathrm{CO}_{2}$ reduction, even though $40 \%$ of U.S. corn and $30 \%$ of soybeans are devoted to their production. Bioethanol is traced through its Carbon Cycle and shown to be both energy inefficient, and an inefficient use of biomass carbon. Both biofuels and $\mathrm{CO}_{2}$ sequestration reduce FUTURE $\mathrm{CO}_{2}$ emissions from continued use of fossil fuels. They will not remove $\mathrm{CO}_{2} \mathrm{ALREADY}$ in the atmosphere. The only way to do that is to break the Carbon Cycle by growing biomass from atmospheric $\mathrm{CO}_{2}$ and sequestering biomass CARBON. Theoretically, sequestration of only a fraction of the world's tree leaves, which are renewed every year, can get the world to Net Zero $\mathrm{CO}_{2}$ without disturbing the underlying forests.
\end{abstract}

Keywords: carbon dioxide; global warming; sequestration; carbon cycle; biomass sequestration, carbon sequestration

\section{Introduction}

$\mathrm{CO}_{2}$ is the dominant greenhouse gas component leading to Global Warming. If man does nothing to intervene, atmospheric $\mathrm{CO}_{2}$ levels are projected to more than double to over $900 \mathrm{ppmv}$ by 2100 (Lindsey, 2020). This paper begins on purpose with a short review of previous proposed solutions to show that none of them are a complete solution to achieve Net Zero $\mathrm{CO}_{2}$. Some parts of this review are moved to the Supplemental Input (SI) so the reader can choose to read or ignore that material. Sequestration of biomass carbon, in particular tree leaves, is proposed as a simple (in concept) method to achieve Net Zero $\mathrm{CO}_{2}$.

The Carbon Cycle is misunderstood by many. There are those who believe planting more trees will lead to a reduction in atmospheric $\mathrm{CO}_{2}$. If one follows trees through their life cycle, trees are sustainable. They do pull $\mathrm{CO}_{2}$ from the air during their life. However, in unmanaged forests, trees lose their leaves every year, which decompose and release their stored carbon back to the atmosphere. At the end of their life, trees die, decompose, and release the carbon stored in their trunks and branches. Trees take care of themselves. However, over their entire life and death cycle, they will not lead to a net reduction in $\mathrm{CO}_{2}$ that is ALREADY in the atmosphere.

Biofuels have been proposed to reduce $\mathrm{CO}_{2}$ buildup from vehicles. Biofuels do play a role in reducing FUTURE emissions of $\mathrm{CO}_{2}$ from the burning of fossil fuels that they displace. However, 
they come at an economic and societal cost. Almost $40 \%$ of the U.S. corn crop is devoted to fuel ethanol production. Biofuels would at best be sustainable. However, they are not, when the fuel required to plant, fertilize, harvest, transport the carbon source, and fuel used in the biofuel processes is considered. Bioethanol from corn will be traced through its Carbon Cycle and will be shown to be both energy inefficient, and an inefficient use of biomass for reducing $\mathrm{CO}_{2}$. Biofuels from other sources such as cellulosic biomass will be discussed, and a status report will be provided for those technologies.

The technologies for $\mathrm{CO}_{2}$ sequestration from point sources will be discussed. The bottom line is: We know how to do it, using modifications of proven technologies that have been used for many years. However, cost and scaleup will be shown to be issues. $\mathrm{CO}_{2}$ sequestration can reduce FUTURE $\mathrm{CO}_{2}$ going to the atmosphere from continued burning of fossil fuels. It will be a necessary tool in combatting global warming. However, it will not reduce the $\mathrm{CO}_{2}$ ALREADY in the atmosphere and unsequestered $\mathrm{CO}_{2}$ from the continued burning of fossil fuels, which is needed to supply the world's energy demand.

Proper understanding of the Carbon Cycle will show that the only way to reduce the $\mathrm{CO}_{2}$ ALREADY in the atmosphere is to grow biomass and removed it from the Carbon Cycle. Some thoughts on how to do this will be presented.

First, it is important to understand the energy scene, i.e., what fuels are used and where they are used, and to examine the current world energy consumption by fuel source, and the amount of $\mathrm{CO}_{2}$ currently being generated each year to understand the magnitude of the problem and to prioritize efforts.

\section{The Energy Scene}

The U.S. Energy Information Authority (EIA) provides a database that tracks primary energy production and disposition for the U.S., and other world regions [1]. BP provides its yearly Statistical Energy Review [2].

Fig. 1 shows the U.S. 2016 primary energy source and sector in which the energy is used. (EIA, 2017). The three largest sources are petroleum $(37 \%)$, natural gas $(29 \%)$, and coal $(15 \%)$. The reality is that in 2016 only about $10 \%$ of primary energy came from renewables.

The numbers on the left of the lines connecting source to sector show the percentage of a source that goes to a corresponding sector. The major sectors are transportation $(29 \%)$, industry $(22 \%)$, and electric power (39\%). Industrial use accounts for $22 \%$ and residential and commercial accounts for $11 \%$. Renewables accounted for only about $10 \%$.

The numbers on the right of Fig. 1 show the percentage of energy used in a sector that comes from the corresponding source. Thus, $71 \%$ of petroleum goes to the transportation section, $23 \%$ to industry, and only minor amounts to residential and commercial and electric power sectors. Natural gas usage is split almost evenly amongst industrial, residential and commercial, and electric power, with very little to transportation. Coal and nuclear are almost exclusively used to generate power. 


\section{U.S. primary energy consumption by source and sector, 2016} Total $=97.4$ quadrillion British thermal units (Btu)

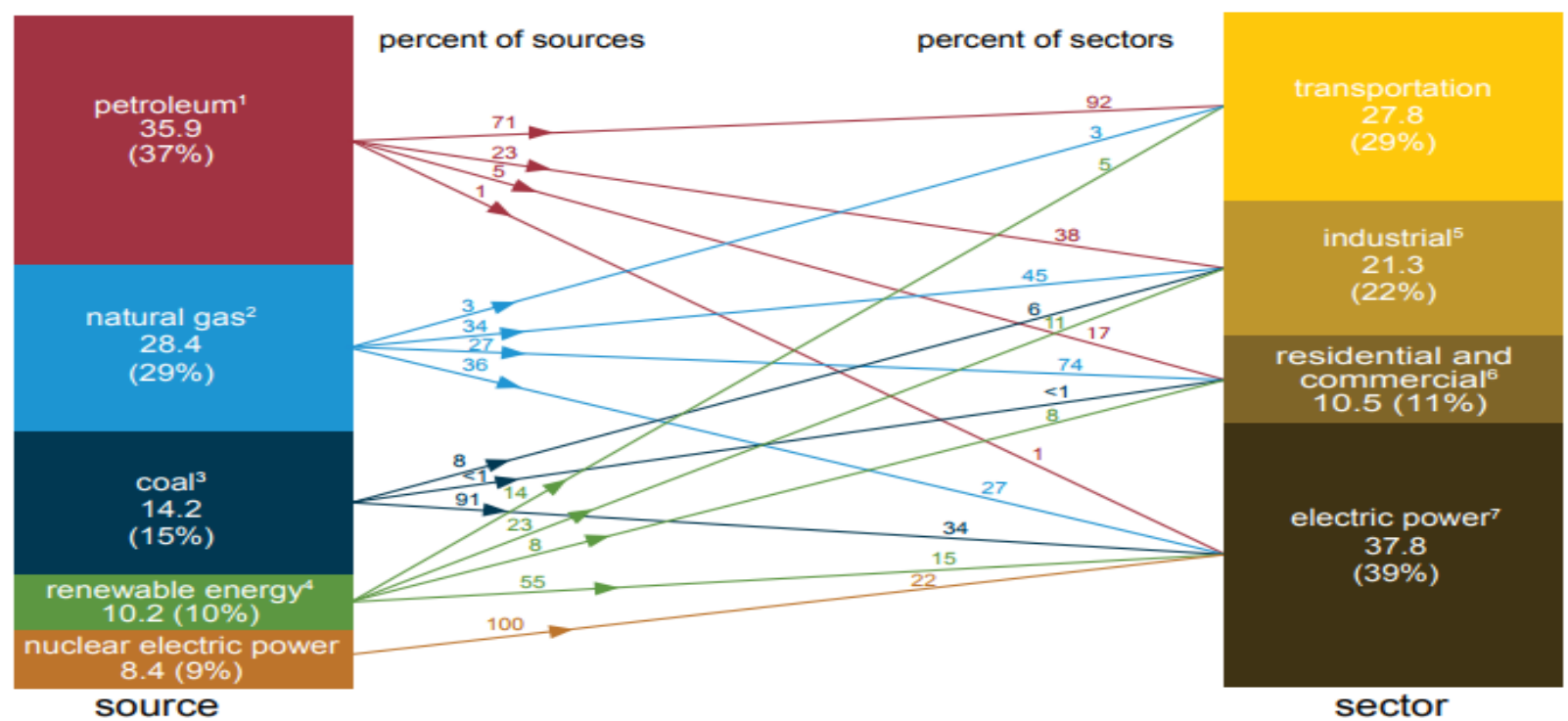

Figure 1. U.S. Primary energy consumption by source and sector, 2016

Source: U.S. primary consumption, EIA (2017) [1].

Fig. SI1 shows the magnitude of the $\mathrm{CO}_{2}$ problem. In 2016, $\mathrm{CO}_{2}$ emissions were 36 Billion tons. The world has a huge $\mathrm{CO}_{2}$ problem that is going to take a variety of huge solutions. Fig. 1 shows the U.S. energy demand. World energy demand is different. In particular, coal represents a much higher fraction of energy demand in China. China dominates world energy demand, and thus, it is not surprising that coal and coke (a heavy ends solid refinery byproduct that can be substituted for coal) represents the largest source of $\mathrm{CO}_{2}$ emissions, as shown in Fig. SI2, and that Asia and Oceana represented almost $50 \%$ of world $\mathrm{CO}_{2}$ emissions in 2016 (Fig. SI3) Coal usage in China exceeds that in the rest of the world combined, as shown in Fig. SI4.

Fig. SI5 shows 2018 U.S. primary energy consumption by source. It has changed little from 2016. This Figure also shows a detailed breakdown of renewables energy. In 2018, biofuels accounted for only $20 \%$ of renewables energy, which account for only $11 \%$ of total U.S. energy demand. As shown in Fig. 1, 92\% of energy for transportation came from petroleum, and 37\% of petroleum went to transportation. It is impractical to sequester $\mathrm{CO}_{2}$ from vehicles. A partial answer for $\mathrm{CO}_{2}$ from vehicles has come from biofuels. Biofuels do replace $\mathrm{CO}_{2}$ from fossil fuels with renewable $\mathrm{CO}_{2}$ coming from biomass grown from $\mathrm{CO}_{2}$ pulled from the atmosphere by photosynthesis. However, tracing bioethanol through its Carbon Cycle will show it to be energy inefficient and an inefficient use of biomass carbon. Thus, a $\mathrm{CO}_{2}$-free energy source is needed to supply transportation.

Finding a $\mathrm{CO}_{2}$-free source of energy for transportation would also take care of reducing $\mathrm{CO}_{2}$ from petroleum. A typical large complex U.S. refinery converts a medium heavy sour crude into about $6 \%$ lights (LPG), 47\% gasoline, 33\% distillates, and 14\% heavies (heavy fuel oil, coke, and asphalt) [3]. Distillates include diesel, kerosene, and jet fuel. European refineries produce more diesel and less gasoline. As noted above, overall, 71\% of petroleum went to transportation in 2016.

Fig. SI5 also shows the EIA projection for energy source shifts out to 2050. The fraction of energy from renewables is projected to double. The Figure shows detail on where the renewables growth is assumed to come from. The absolute amount of electricity from wind is projected to double. Solar is projected to increase by a factor of 9 . Is that a reasonable projection? For a stark reality of the promise and deception of renewables, see the recent film "Planet of the Humans" available on YouTube [4]. If it is to come at the residential level, it would require huge individual homeowner investment. Natural gas has become cheap and abundant in the U.S. after the advent of fracking. EIA projects that the fraction of electricity coming from natural gas remains about 
constant out to 2050. It is still a very significant percentage and a significant percentage of $\mathrm{CO}_{2}$ production. Thus, a means to sequester $\mathrm{CO}_{2}$ during the production of electricity from natural gas is needed, especially if the projected increase of electricity from solar falls short.

Will projections for a great increase in renewables energy come true? R. Malhorta of SRI said the world will need the equivalent energy from 7-9 cubic miles of oil (Strange units. I prefer barrels) to satisfy the incremental world energy needs to the year 2050 [5]. He argues that renewables cannot provide a complete solution to those needs stating that just 1 (of 7-9 needed) cubic mile of oil would require:

- 200 hydroelectric dams the size of the 3 Gorges dam

(1 every quarter for 50 years)

- 2500 nuclear plants the size of the Diablo Canyon reactor

(1 per week for 50 years)

- 7700 soar panel parks $10 \mathrm{x}$ the world's largest

(3 per week for 50 years)

- 3 million windmills

(1200 per week for 50 years)

- 4.2 billion solar roofs

(250k roofs per day for 50 years)

Thus, he argues it is impractical to think that petroleum and coal can be displaced completely. That is reality! Energy reduction alone cannot get the world to Net Zero $\mathrm{CO}_{2}$. In fact, world energy demand will increase with increase in population, despite energy conservation efforts. Clearly, other solutions are needed.

\section{Understanding the Carbon Cycle}

A cartoon depicting the Carbon Cycle is provided in Fig. 2. Plants get essentially all of their carbon for their growth from $\mathrm{CO}_{2}$ in the atmosphere via photosynthesis, forming carbohydrates [6]. The photosynthesis reaction can be represented crudely by the reaction:

$6 \mathrm{CO}_{2}+6 \mathrm{H}_{2} \mathrm{O}+$ sunlight $\rightarrow \mathrm{C}_{6} \mathrm{H}_{12} \mathrm{O}_{6}$ (glucose) $+6 \mathrm{O}_{2}$

The simplest formula representation of carbohydrates is $\mathrm{CH}_{2} \mathrm{O}$.

Plant matter is fed to animals and plants and animals are fed to humans. Animals and humans respire the bulk of the carbon in their food as $\mathrm{CO}_{2}$ when they exhale. Animals and humans grow and thus serve as temporary storage vessels for some of the carbon. However, plants, animals, and humans eventually die and decompose and release their carbon back to the atmosphere as $\mathrm{CO}_{2}$, completing their part of the Carbon Cycle. Plants and animals that fall to the ground or are buried (such as corn silage) decompose via the action of worms, fungi, and bacteria. They feed on the decomposing plants, and respire $\mathrm{CO}_{2}$, and thus, play an important role in the Carbon Cycle. Normally there is no net buildup of carbon in the soil. Soil carbon generally reaches a steady state carbon level of 1-4 wt\% [7]. 


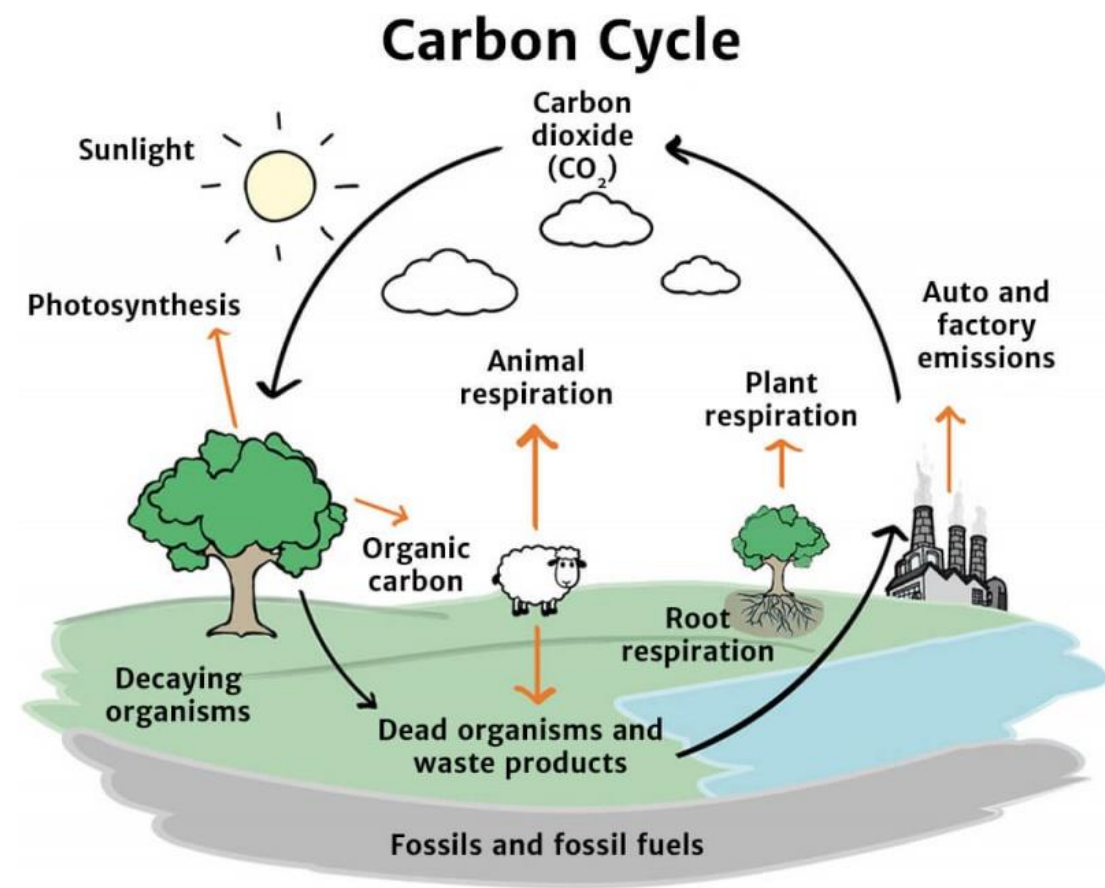

Figure 2. The Carbon Cycle.

Source: Alamy (2020) The Carbon Cycle [8].

While plants receive all of their carbon from the atmosphere, they draw water as a source of hydrogen, nitrogen, phosphorous and other nutrients such as potassium from the soil. The enzyme that catalyzes photosynthesis contains both nitrogen and phosphorous [9]. In the natural Carbon Cycle, dead plant material returned to the soil feeds the worms, bacteria, and fungi that decompose plant matter releasing the needed N, P, K, and other nutrients back into the soil. That is part of the cycle. Intensive farming requires some artificial fertilizer to provide some of the nutrients.

Thus, the normal Carbon Cycle is sustainable. There is no net movement of $\mathrm{CO}_{2}$ in the atmosphere and no net movement of carbon into the ground. The only way to remove $\mathrm{CO}_{2}$ ALREADY in the atmosphere is to break the cycle. Biomass must be grown from $\mathrm{CO}_{2}$ in the atmosphere and the biomass itself must be sequestered (CARBON sequestration, not $\mathrm{CO}_{2}$ sequestration).

\section{Bioethanol and The Carbon Cycle}

The Kyoto Protocol was adopted on December 11, 1997 and entered into force on February 16, 2005 [10]. It called for major industrial countries to reduce emissions of greenhouse gases.

The European response was to shift from gasoline to diesel at the lobbying of the major auto companies. Diesel engines do provide better fuel economy than gasoline vehicles. However, diesel vehicles have issues with emissions of carcinogenic particulates and NOX. We now know that some European car manufacturers cheated on emissions testing, and diesel engines have contributed to health issues [11].

The U.S. refineries were configured to make gasoline, with large catalytic reformer and Fluid Catalytic Cracking (FCC) capacity installed in the 1960's and 1970's to make high octane gasoline in response to lead phase out. Thus, the U.S. remained in favor of gasoline. To meet the requirements of the protocol, the U.S. mandated the blending of bioethanol. The gasoline pool has reached the "blending limit," such that essentially $10 \%$ of the U.S gasoline pool is bioethanol [12]. $10 \mathrm{vol} \%$ is the limit for normal gasoline because ethanol is corrosive and degrades elastomers in gaskets of normal gasoline engines. Flex fuel vehicles are now sold that can accept E85 (85\% ethanol), but E85 is not widely available and has not been widely adopted by the public. 
One of the claimed benefits for bioethanol is that the U.S. would become less dependent on foreign oil. With the advent of fracking to release tight oil and gas, and the discovery of oil in the western U.S., the U.S. has become the largest producer of oil in the world. , and now exports about as much finished gasoline and much more oil that the amount of bioethanol blended into gasoline as shown in Fig. 3 [12-15]. Thus, the argument that bioethanol is needed for U.S. energy independence no longer holds.

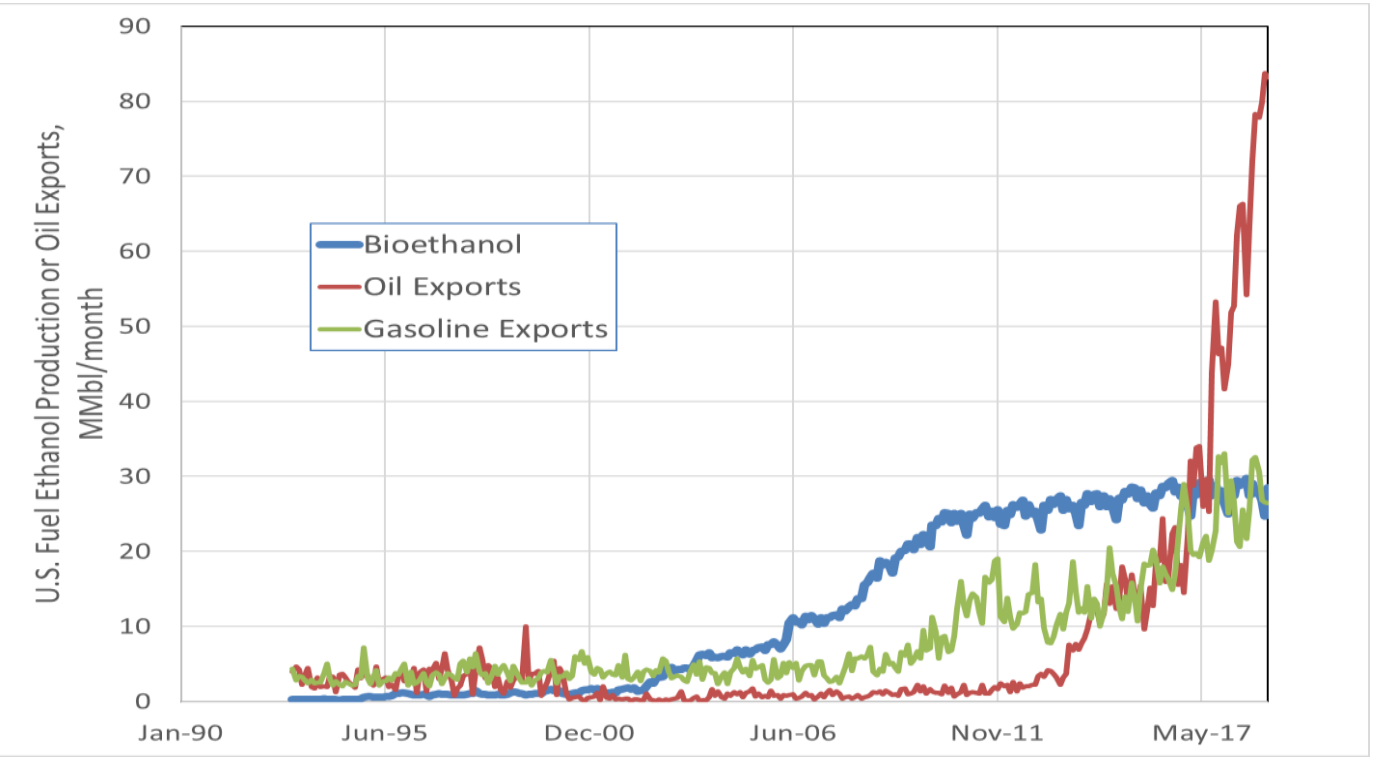

Figure 3. U.S. bioethanol used in gasoline (blue), oil exports (red), and gasoline exports (green) Data Sources: EIA [12-15].

Another early argument for bioethanol was that blending oxygenates into gasoline would reduce tail pipe emissions of carbon monoxide (CO). However, a study in Mexico City converters showed no indication that $\mathrm{CO}$ emissions are reduced with increasing oxygenate concentration for vehicles with 3-way converters [16]. Everything that goes into the converters comes out clean.

In the U.S. essentially all of bioethanol is made from corn. However, as noted above, transportation is only a fraction of primary energy sector demand, and gasoline is only a fraction of transportation, such that bioethanol represents only about $1.7 \%$ of total U.S. energy consumption. Biodiesel penetration is even lower at about $3 \%$ of diesel, which is only a fraction of distillates which are lower volume than gasoline in the U.S. [17].

Bioethanol production comes at great economic and social cost and has other issues. The U.S. Department of Agriculture (USDA) indicates that about $40 \%$ of the U.S. corn crop is devoted to bioethanol production [18]. That is diverting a lot of potential food into gas tanks! There are other issues. Bioethanol is hygroscopic. It picks up water in pipelines. It must be blended near gas stations. This adds both capital, labor, and energy costs.

Let me repeat, plants get all of their carbon from $\mathrm{CO}_{2}$ in the air via photosynthesis. Let's track that carbon through the bioethanol production and Carbon Cycle.

Do you know how much air containing only $400 \mathrm{ppmv}$ of $\mathrm{CO}_{2}$ is required to produce an acre of corn? The answer may surprise you. The calculation is provided in a spreadsheet in Section SI.1. It takes the air above about 0.85 acres of land up to the edge of the troposphere $(35,000 \mathrm{ft})$ to feed the growth of one acre of corn. In 2019, 89.7 million acres of corn were planted in the U.S. [18]. The U.S. land area is $2.43 \mathrm{E} 9$ acres. Thus, while corn is the largest crop in the U.S. only about $3.7 \%$ of the U.S. land area is devoted to corn. Of course, not all U.S. land and an even lower fraction of total world land is suitable for growing corn [19]. Thus, it is not reasonable to expect that corn ethanol production can be increased much further.

Corn ethanol is produced by converting starch in corn kernels to sugar and fermenting the sugar to ethanol. Starch is a polymer of the 6-carbon sugar glucose. It occurs in two forms, amylose, a 
smaller linear polymer, and amylopectin, a larger branched polymer (Fig. SI6). Polymerization occurs by condensing two glucose molecules releasing water. Starch is converted to sugars by the reverse reaction, catalyzed by enzymes. The glucose sugar is then fermented to form bioethanol.

The processes for converting corn starch to sugars and then fermenting to bioethanol are discussed in Section SI.2, along with a process flow diagram for the current more economic corn ethanol process, the Dry Grind Ethanol Process.

$\mathrm{CO}_{2}$ is shown as a product of the Dry Grind Process (Fig. SI.7). Why?

The simplified molar formula for starch is $\mathrm{C}_{6} \mathrm{H}_{10} \mathrm{O}_{5}$, and hydrolysis to glucose can be represented as:

$\mathrm{C}_{6} \mathrm{H}_{10} \mathrm{O}_{5}+\mathrm{H}_{2} \mathrm{O} \rightarrow \mathrm{C}_{6} \mathrm{H}_{12} \mathrm{O}_{6}$

(1.00 gm starch $\rightarrow 1.11$ gm glucose)

The glucose is fermented to ethanol via the reaction:

$\mathrm{C}_{6} \mathrm{H}_{12} \mathrm{O}_{6} \rightarrow 2 \mathrm{C}_{2} \mathrm{H}_{5} \mathrm{OH}+2 \mathrm{CO}_{2}$

$1.11 \mathrm{gm} \rightarrow 0.568 \mathrm{gm}+0.542 \mathrm{gm}$

Thus, fermentation converts 2 of the 6 carbons in glucose to $\mathrm{CO}_{2}$, before the ethanol does any useful work in a gasoline engine. $\mathrm{CO}_{2}$ liberation during fermentation is why champagne is bubbly!

There are over 200 ethanol plants in the U.S. [20]. $\mathrm{CO}_{2}$ sequestration is possible by absorption or adsorption. However, only a handful recover $\mathrm{CO}_{2}$. The rest vent to atmosphere, because recovering $\mathrm{CO}_{2}$ is expensive, the value of the $\mathrm{CO}_{2}$ byproduct is low, and most of these plants are in remote regions. That is reality!

One can already see why corn ethanol is a very inefficient use of the carbons in the corn plant biomass to displace fossil fuel carbons. However, corn kernels are only about $60 \mathrm{wt} \%$ starch and the corn plant is only about $35 \mathrm{wt} \%$ corn kernels [21]. What happens to the rest of the corn plant carbon as it completes it Carbon Cycle? First, let's take a look at the amount of energy required to separate the water from the alcohol.

Water and ethanol form an azeotrope. Thus, it is not possible to use simple distillation to meet the water specification for fuel grade ethanol. It requires either azeotropic distillation or drying over molecular sieves. Older plants used azeotropic distillation. U.S. Patent 4,217,178 discloses a heat integrated ethanol plant with azeotropic distillation [22]. The energy requirement for the distillations is $239.4 \mathrm{~kJ} / \mathrm{gm}$ mol ethanol. The heat of combustion of ethanol is $1360 \mathrm{~kJ} / \mathrm{gm} \mathrm{mol}$. Thus, the azeotropic distillation step alone requires $17.8 \%$ of the heat of combustion of the product. A full economic model of a Dry Grind ethanol plant, including all utilities costs is provided in Kwiatkowski, et al. [23]. The modeled plant uses a molecular sieve drier after distilling the beer to near the azeotrope. That is lower energy than azeotropic distillation. However, with steam cost converted to natural gas equivalent, the total plant natural gas equivalent usage that is $87 \%$ higher than the azeotropic steam heat of US 4,217,178. Even though steam for the beer column alone will be less than the azeotropic distillation step, the total plant needs heat elsewhere (cooking the mash, drying the DDGS, etc.) Thus, bioethanol production is not only an inefficient use of corn biomass carbon, but parasitic energy costs are high.

Corn ethanol is not currently economic without huge government subsidies of over $\$ 1 /$ gallon, or billions of taxpayer dollars per year [24]. It is not the intent of this paper to pass judgements on cost. Rather, one must be aware of true costs of production. So, what can bioethanol plants do better to reduce $\mathrm{CO}_{2}$ going to the atmosphere? There should be a mandate to recover the $\mathrm{CO}_{2}$ vented from the fermenters, and the cost of sequestration must be borne by the consumers of gasoline. Or better yet, an alternate solution to hydrocarbon-fueled vehicles must be found.

How much $\mathrm{CO}_{2}$ can be sequestered from U.S. bioethanol production? U.S. nameplate ethanol production is 16,868 $\mathrm{MMgal} / \mathrm{yr}$ [18]. With $2 \mathrm{~mol} \mathrm{CO}_{2}$ generated per mol of ethanol, sequestering all of the $\mathrm{CO}_{2}$ would remove $106 \mathrm{MM}$ tons/year $\mathrm{CO}_{2}$. This is a big number, but only $0.3 \%$ of the amount of the 36,000 MMtons/yr $\mathrm{CO}_{2}$ generated each year worldwide. Thus, other solutions are needed. 
Corn kernels are only about $60 \mathrm{wt} \%$ starch and the corn plant is only about $35 \mathrm{wt} \%$ corn kernels. What happens to the rest of the corn plant? Most is plowed back into the ground, where it decomposes and releases its carbon back to the atmosphere.

What if the U.S. corn plants used to produce ethanol were permanently sequestered? Corn production in the U.S. peaked in the 2017/2018 season at 14,609 MMBushels, with $38.4 \%$ going to fuel ethanol. At $35 \mathrm{wt} \%$ corn kernels, the weight of corn plants devoted to ethanol was 1.17 billion tons [18]. Representing corn as $\mathrm{CH}_{2} \mathrm{O}$, secure burial of those corn plants would have pulled $406.9 \mathrm{MM}$ metric tonnes of $\mathrm{CO}_{2}$ from the atmosphere compared to world $\mathrm{CO}_{2}$ production of 36 billion tons or $1.1 \%$. Thus, simply burying the corn plants would be a more efficient means of pulling $\mathrm{CO}_{2}$ ALREADY in the atmosphere, compared to corn ethanol, which is less than sustainable. However, this is nowhere close to what is needed to keep up with the $\mathrm{CO}_{2}$ entering the atmosphere from the burning of fossil fuels. Thus, the U.S. cannot farm its way out of the $\mathrm{CO}_{2}$ problem.

The U.S. and Brazil account for about $85 \%$ of the world ethanol production. Brazil uses cane sugar as the main raw material, and the energy efficiency of those plants is improved by burning bagasse (waste after squeezing out the cane syrup) to generate power. However, Google pictures of Brazil ethanol plants and you will see that burning bagasse is very dirty and pollution generating, and there is a huge negative environmental impact of clear-cutting forests to grow sugar cane.

\section{Cellulosic Bioethanol}

Cellulosic ethanol has been touted as the Holy Grail for bioethanol. Advantages would be cheap, non-food feedstock. However, its implementation has been slow. A Sandia study indicated that 70 billion gallons of cellulosic ethanol should be "possible" by 2030 [25]. However, only about $15 \mathrm{MM}$ gal were produced in 2018 [26]. That is reality! Why? There are continued economic and technical challenges which are discussed in Section SI.3.

\section{Biodiesel}

Biodiesel is produced by the transesterification of vegetables oils with methanol. The reaction is:

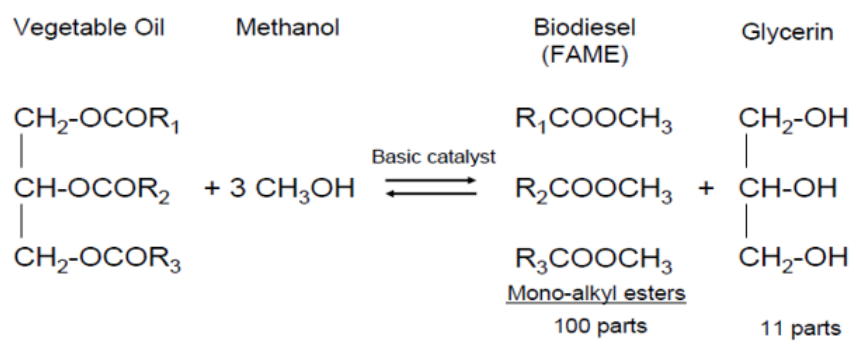

Economic production of methanol requires large plants to achieve economy of scale, and the ethanol is made from cheap natural from fracking [27]. Thus, the methanol comes from a fossil fuel. The reaction makes fatty acid methyl esters (FAME) having carbon numbers in the diesel boiling range. FAME has cetane and other properties that make it acceptable for blending into diesel. It is not used neat, and thus, the diesel pool will continue to rely on diesel from fossil fuels

Petroleum diesel is comprised of a more or less normal distribution of hydrocarbons from about C9 to $\mathrm{C} 23$, peaking around C16. Vegetable oils from different sources produce FAME having carbon number distributions as shown in Table S1. U.S. biodiesel uses primarily soybean oil. Rapeseed oil is the preferred feedstock in Europe. For the $2017 / 2018$ season, about $30 \%$ of U.S. soybeans were 
used for biodiesel [28]. That is a huge diversion of crops to satisfy only about $3 \%$ of the U.S diesel pool. That is the reality! One issue for biodiesel is the production of about 11 parts of glycerin as a nuisance byproduct per 100 units of FAME.

\section{Other Routes For Biomass to Fuel}

Some other routes for converting biomass to fuels are discussed in Section SI.4. Most are still in their infancy and at a scale that does not make a significant contribution to the $3600 \mathrm{MMtons} / \mathrm{yr} \mathrm{CO}_{2}$ removal needed to keep up with current generation.

\section{8. $\mathrm{CO}_{2}$ Sequestration Technologies}

$\mathrm{CO}_{2}$ sequestration can remove $\mathrm{CO}_{2}$ from industrial furnaces, including furnaces used in the generation of electricity from coal or natural gas. Thus, it can target $\mathrm{CO}_{2}$ generation from the industrial and electric power sectors, which together account for over $50 \%$ of $\mathrm{CO}_{2}$ generation. This is substantial, but not a complete solution to the $\mathrm{CO}_{2}$ problem.

The message for $\mathrm{CO}_{2}$ sequestration is: We know how to do it, with proven technologies, some of which have been practiced for close to 100 years. It is going to cost money, and scale-up to the size needed is going to be an issue.

Three ways have been proposed for $\mathrm{CO}_{2}$ sequestration, High level bullet points for some of the advantages and disadvantages are provide below and will be discussed in more detail.

\section{- Direct $\mathrm{CO}_{2}$ Capture from air}

- Dilute (400 ppmv $\left.\mathrm{CO}_{2}\right)$

- Must move massive quantities of air

- Can remove $\mathrm{CO}_{2}$ ALREADY in the air

\section{- Post-Combustion $\mathrm{CO}_{2}$ Capture}

- Fuel burned and $\mathrm{CO}_{2}$ removed from furnace stack gas

- $\mathrm{CO}_{2}$ still dilute (5-10 vol\% depending on fuel source and composition) due to nitrogen from combustion air

- Flue gas near atmospheric pressure, and must be blown (compressed) through absorber or adsorption bed

- Can be applied to flue gas from natural gas or coal-fired power plants making both "clean"

- Appropriate to sequester $\mathrm{CO}_{2}$ from massive EXISTING furnace installed base

- Can be retrofitted to existing furnaces

\section{- Pre-Combustion $\mathrm{CO}_{2}$ Capture}

- Requires new-build integrated power plants

- For natural gas fuel, basically modification of a steam reforming $\mathrm{H}_{2}$ plant which has been practiced for nearly 100 years

- Steam reforming of natural gas or partial oxidation of coal to form syn gas $\left(\mathrm{CO}+\mathrm{H}_{2}\right)$ 
- Water-gas shift to produce $\mathrm{CO}_{2}$ and more $\mathrm{H}_{2}: \quad \mathrm{CO}+\mathrm{H}_{2} \mathrm{O}=\mathrm{CO}_{2}+\mathrm{H}_{2}$

$\circ \mathrm{CO}_{2}$ removed by adsorption or adsorption, before producing a clean burning $\mathrm{H}_{2}$ fuel (pre-combustion)

- In combined cycle power plant, exothermic reactions produce steam to turn turbines to generate electricity

- Hydrogen can be burned to generate more steam to make more electricity or exported for refinery or chemical use or other fuel use

○ The so-called "Hydrogen Economy"

All $\mathrm{CO}_{2}$ sequestration technologies will face the issue of what to do with the $\mathrm{CO}_{2}$ product, especially at the scale needed just to keep up with the new introduction of $\mathrm{CO}_{2}$ into the atmosphere from continued use of fossil fuels (36 billion tons/yr). Permanent disposal of sequestered $\mathrm{CO}_{2}$ is discussed in Section SI.6.

\section{$\underline{\text { 8.1 Direct } \mathrm{CO}_{2}} \underline{\text { Capture From Air }}$}

There are companies trying to commercialize pulling $\mathrm{CO}_{2}$ directly from air [29]. The obvious issue is the need to move massive quantities of air through an absorber or adsorber to recover even a trivial amount of $\mathrm{CO}_{2}$. In my opinion, this is simply not practical.

\subsection{Post-Combustion $\mathrm{CO}_{2}$ Capture}

A process schematic for post-combustion $\mathrm{CO}_{2}$ capture is shown in Fig. SI10. The heart of the process is adsorption into a solvent, typically an amine, followed by stripping the $\mathrm{CO}_{2}$ from the amine via distillation. Typical solvents include MEA (monoethylamine) and DEA (diethylamine), which requires less energy to strip the amine than MEA.

This technology can be retrofitted on the massive installed base of existing furnaces of power plants, and refinery and chemical processes. Thus, it should be an essential part of a comprehensive attack on global warming from $\mathrm{CO}_{2}$.

In Post-Combustion capture, flue gas is near atmospheric pressure and must be blown through an absorber or adsorption bed. This requires a blower (low pressure compressor) and its associated capital and operating cost. One issue for post-combustion $\mathrm{CO}_{2}$ capture is that the $\mathrm{CO}_{2}$ is still dilute due to nitrogen from the air used to combust the fuel. The technology can be retrofitted to either natural gas- or coal-fired power plants. The concentration of $\mathrm{CO}_{2}$ in the flue gas can be calculated from the composition of the fuel. For methane combustion, the reaction is:

$\mathrm{CH}_{4}+2 \mathrm{O}_{2}+2 * 79 / 21 \mathrm{~N}_{2} \rightarrow \mathrm{CO}_{2}+2 \mathrm{H}_{2} \mathrm{O}+2 * 79 / 21 \mathrm{~N}_{2}$

Since combustion air is $79 \mathrm{~mol} \% \mathrm{~N}_{2}$, it dilutes the $\mathrm{CO}_{2}$ product.

$\mathrm{CO}_{2}$ concentration would vary from about $5 \mathrm{~mol} \%$ for natural gas to $10 \mathrm{~mol} \%$ for coal due to its higher $\mathrm{C}: \mathrm{H}$ ratio, which depends on the grade of coal.

This technology works and removal of acid gases like $\mathrm{CO}_{2}$ and $\mathrm{H}_{2} \mathrm{~S}$ from refinery streams has been practiced for about 100 years. Application to recover $\mathrm{CO}_{2}$ from power plant flue gas is in the demonstration stage. A photo of Alabama Power's Plant Barry demonstration unit is shown in Fig. SI11 [30-32]. This photo shows the issue: scale-up. This demo unit pulls $\mathrm{CO}_{2}$ from the flue gas of the equivalent of $25 \mathrm{MW}$ of power generation. The plant occupies a plot space of $90 \mathrm{~m}$ by $45 \mathrm{~m}$. A large power plant may be $1000 \mathrm{MW}$, and thus, a $\mathrm{CO}_{2}$ capture plant to treat the entire power plant effluent will be massive. Production of amine is energy intensive, and a massive amount of amine 
would be needed to treat significant amounts of flue gas. Thus, scale up is an issue. That is the reality!

The technology has now been scaled up to commercial scale. The Petra Nova power plant began commercial sequestration from flue gas of the equivalent of $240 \mathrm{MW}$ (37\% of the total plant emissions) in January 2017 [33]. It is a start, but we have a long way to go. That is reality!

\section{$\underline{8.3 \text { Pre-Combustion } \mathrm{CO}_{2} \text { Capture }}$}

Pre-Combustion $\mathrm{CO}_{2}$ capture involves steam reforming or partial combustion of a fuel to form synthesis gas (a mixture of $\mathrm{CO}$ and $\mathrm{H}_{2}$ ). In principal, any fuel containing carbon can be converted to synthesis gas.

The $\mathrm{CO}$ is converted by reacting with water to form $\mathrm{CO}_{2}$ and more $\mathrm{H}_{2}$ via the water gas shift reaction. Steam reforming is preferred for natural gas. The reaction for methane is:

$\mathrm{CH}_{4}+\mathrm{H}_{2} \mathrm{O}=\mathrm{CO}+3 \mathrm{H}_{2}$

For coal, partial oxidation is preferred:

$\mathrm{C}+1 / 2 \mathrm{O}_{2} \rightarrow \mathrm{CO}$

The steam reforming reaction forms some hydrogen directly.

Both steam reforming and partial oxidation reactions are followed by the water-gas shift reaction to form more hydrogen and $\mathrm{CO}_{2}$ :

$\mathrm{CO}+\mathrm{H}_{2} \mathrm{O}=\mathrm{CO}_{2}+\mathrm{H}_{2}$

The $\mathrm{CO}_{2}$ is captured by absorption or adsorption. One advantage for pre-combustion capture compared to post-combustion is that the water-gas shift reactor effluent is at moderate pressure (1020 barg). Thus, it does not need a separate blower to move it through an absorber or adsorber, and adsorption processes that used pressure swing are possible.

Steam reforming of methane is the technology used in hydrogen plants, a technology that has been used for nearly 100 years to produce supplemental hydrogen for refineries and chemical processes. A schematic of a steam reforming hydrogen plant is provided in Fig. SI12, and a process description is provided in Section SI.5.

Partial oxidation of coal or other high carbon content fuels is usually done in open flame reactors, preferably using pure oxygen, because air would dilute the synthesis gas by the nitrogen. Thus, for coal, the Oxy-Fuel Pre-Combustion process shown in Fig. SI12 may be preferred [34]. One obvious drawback is the need for an air separation plant to generate the pure oxygen. One can envision an Oxy-Fuel Pre-Combustion plant, where the nitrogen from the air separation plant is used with the hydrogen product to produce ammonia.

In summary, we know how to do $\mathrm{CO}_{2}$ capture via Pre-Combustion or Post-Combustion. It uses proven technology. It works. It will cost money. How much money?

The efficiency of a power plant can be defined as the amount of electricity generated per unit of fuel to the process. $\mathrm{CO}_{2}$ capture does not come free. The energy required by $\mathrm{CO}_{2}$ capture is parasitic energy, and the extra fuel required to do the $\mathrm{CO}_{2}$ stripping, run pumps, cooling tower fans, and compressors has the effect of reducing power plant efficiency, which is reflected in an increase in the net back price for the electricity. This increase in net back price is often referred to as the "Cost of $\mathrm{CO}_{2}$ Capture." 
The IEA web site has a wealth of information on carbon capture [35-36]. It is highly recommended for those interested in the subject. In the 2007 report, the cost of electricity is estimated for both coal and natural gas with and without various power plant configurations. Projected cost for electricity with carbon capture are shown in Fig. SI14. The relative increase in electricity cost was projected to be $23-40 \%$ higher for coal and $25-60 \%$ higher for natural gas based on then current European pricing and depending on power plant technology (excluding the cost for $\mathrm{CO}_{2}$ transportation and cost for underground storage. The percentage increase in the U.S. would be higher due to cheap natural gas feedstock cost. Cost is higher, but not abhorrent. This is reality! If we want to solve the $\mathrm{CO}_{2}$ problem, this is what it is going to take.

Again, $\mathrm{CO}_{2}$ sequestration should be considered a necessary tool to reduce $\mathrm{CO}_{2}$ emissions from FUTURE continued burning of fossil fuels. Its implementation would have a huge impact. However, it alone cannot get the world to Net Zero $\mathrm{CO}_{2}$.

\subsection{Sequestration of Tree Leaves and Municipal and Yard Waste}

As noted earlier, fossil fuels and $\mathrm{CO}_{2}$ sequestration will prevent FUTURE $\mathrm{CO}_{2}$ from fossil fuels entering the atmosphere. However, as we have seen doing it on a scale needed to meet current and future energy demands is daunting. Furthermore, they are not a complete solution, so other solutions are needed.

Per an understanding of the Carbon Cycle, the only way to remove $\mathrm{CO}_{2}$ ALREADY in the atmosphere is to grow biomass and remove that biomass from the Carbon Cycle. We have already argued that growing corn and algae and sequestering the total mass would have a bigger impact than inefficiently converting only a portion of that biomass (corn kernels) to fossil fuels (See above and the SI). That would pull some $\mathrm{CO}_{2}$ ALREADY in the atmosphere. However, as shown above it is not enough. Sequestering all of the biomass in the $40 \%$ of the U.S. corn crop now devoted to bioethanol would only remove $406.9 \mathrm{MM}$ metric tonnes of $\mathrm{CO}_{2}$ per year compared to the 36 billion tonnes generated. Something else is needed to achieve Net Zero $\mathrm{CO}_{2}$ to the atmosphere.

The answer is secure burial of biomass from other sources, including municipal and yard waste, and biomass generated in forests (tree leaves and wood). By secure burial, we mean permanent burial with provisions taken to prevent decomposition and release of the $\mathrm{CO}_{2}$ to the atmosphere. Currently yard waste is collected, and a portion is used to produce mulch, but it eventually decomposes and releases its carbon back to the atmosphere. Municipal waste is buried in landfills, where it gradually decomposes. It undergoes a combination of aerobic and anaerobic decomposition to produce a biogas.

On average, about half of the volumetric concentration of landfill gas is methane and slightly less than half is $\mathrm{CO}_{2}$. The gas also contains about $5 \%$ molecular nitrogen (N2), less than $1 \%$ hydrogen sulfide $\left(\mathrm{H}_{2} \mathrm{~S}\right)$, and a low concentration of non-methane organic compounds (NMOC), about 2700 ppmv [37]. Methane is a more powerful greenhouse gas than $\mathrm{CO}_{2}$.

Landfills are now designed with underground collection systems, and the gas is typically routed to flares, and burned. Thus, the carbon in the gas is converted to $\mathrm{CO}_{2}$ which goes back to the atmosphere. Some landfills now route the gas to boilers for power generation, or other uses. 
Secure burial of municipal and yard waste in permanent landfills would remove that carbon from the Carbon Cycle and would remove $\mathrm{CO}_{2}$ ALREADY in the atmosphere that would feed the growth of the organic materials in those waste sources. In addition, it would remove $\mathrm{CO}_{2}$ going to the atmosphere from refinery and petrochemical processes used to produce plastics, if plastics are included in the waste to be buried.

The question is how can it be buried securely, prevent it from decomposing and releasing its carbon to the atmosphere? The systems are in place to collect yard and municipal waste in most large cities in the U.S., and elsewhere in the world, so part of the cost is already sunk. The design of secure landfills is beyond the scope of this article. However, I am convinced of man's ingenuity to do it. One thought is that the underground storage caverns proposed for securing sequestered $\mathrm{CO}_{2}$ could be used.

Some municipal waste is starting to be burned to generate renewable power is discussed in Section SI.3. One issue for that application is that even after separation of recyclables, average municipal waste still contains about $20 \%$ non-organics (glass, metal, etc.) that must be separated before the organics can be burned. Secure burial to sequester all of the waste would not require this stringent and costly separation.

How big of a difference could this make? The U.S. EPA keeps statistics on municipal and yard waste generated, and how much is ultimately landfilled [38]. In 2017, the total amount of U.S. municipal and yard waste generated was 267.8 MM short tons. Some is separated and recycled, some is currently burned to generate renewable power, leaving the amount landfilled at $139.6 \mathrm{MM}$ tons, with composition provided in Fig. SI18. The organic component was 112.5 MM tons. That corresponds to $149.6 \mathrm{MM}$ metric tonnes of $\mathrm{CO}_{2}$ if allowed to completely decompose. This compares to the 6480 $\mathrm{MM}$ tons per year $\mathrm{CO}_{2}$ generated in the U.S. and is far short of the $36000 \mathrm{MMtons} / \mathrm{yr} \mathrm{CO}$ currently being generated worldwide. Participation by other countries would help, but clearly not enough to solve our daunting $\mathrm{CO}_{2}$ problem. We need to turn to our other resources for pulling $\mathrm{CO}_{2}$ from the atmosphere: trees, both tree leaves and wood.

The USDA has provided allometric equations for urban tree growth parameters for many species and at numerous locations in the U.S. [39]. The growth equations have been programmed into EXCEL files that are provided in Section SI.7. Dry leaf biomass is calculated for most species and regions where data is available.

As shown in Fig. 4, Dry leaf biomass can be over $100 \mathrm{~kg} / \mathrm{yr}$ for some of the maples and over $400 \mathrm{~kg} / \mathrm{yr}$ for some of the oaks depending on location and age. Mature tree wood weights can be several metric tonnes per tree, as shown in Fig. 5. Leaves currently fall to the ground and decompose each year. Let's assume a conservative average of $50 \mathrm{~kg} / \mathrm{yr}$ dry weight of leaves per tree. If forests were managed, the leaves gathered and permanently securely buried, this would be the equivalent of over $(50 \mathrm{~kg} / \mathrm{yr} \text { dry wgt })^{*}\left(44.01 \mathrm{gm} \mathrm{CO} / 30.03 \mathrm{gm} \mathrm{CH}_{2} \mathrm{O}\right)=73 \mathrm{~kg} / \mathrm{yr} \mathrm{CO}_{2}$ removed from the atmosphere per tree every year.

According to the latest estimate, there are over 3 trillion trees in the world [40]. At $73 \mathrm{~kg} / \mathrm{yr}$-tree $\mathrm{CO}_{2}$ equivalent per tree that is the potential to remove 219 billion metric tonnes $\mathrm{CO}_{2}$, compared to 36 billion tonnes $\mathrm{CO}_{2}$ generated each year. Theoretically sequestering tree leaves could provide a complete solution to our $\mathrm{CO}_{2}$ fossil fuel problem. The potential is enormous. Of course, not all trees are deciduous, or readily accessible. Also, the problem is still daunting. Leaves from about 
$16 \%$ of the world's tree population would be needed. Removal and secure burial of tree wood would help. Harvesting tree wood as a means of $\mathrm{CO}_{2}$ sequestration would be labor intensive and expensive. Furthermore, it is not needed. Harvesting the leaves would suffice. Also, harvesting leaves alone would not disrupt the forest itself. It is best to leave the wood for its current uses (construction, furniture, etc.) Managing new forest plantings should be considered with access provided for leaf collection.

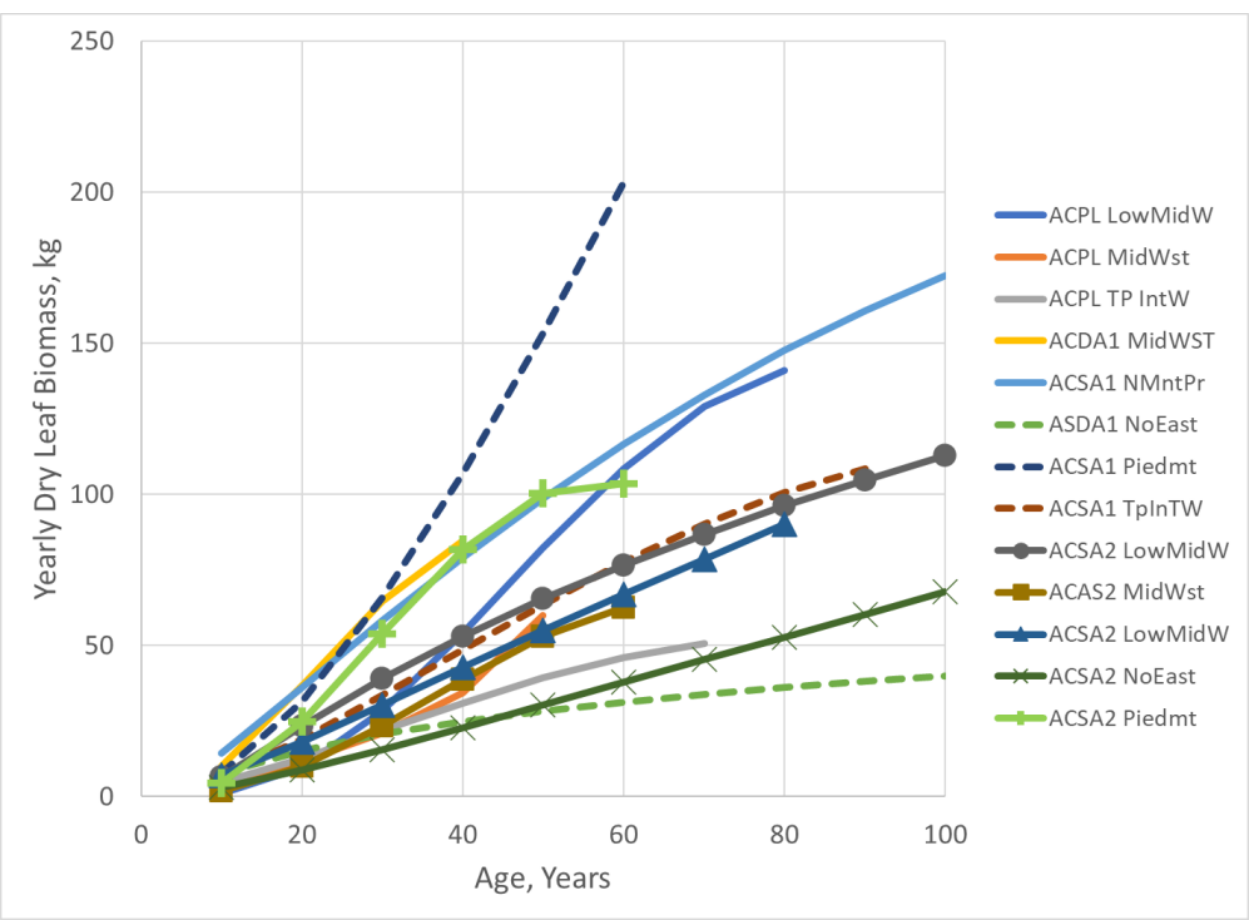

Fig. 4 Yearly dry deaf biomass generation by some maple tree species in various regions of the U.S. Data Source: McPherson, van Doorn, and Peper (2016) [39]. ACPL $=$ Norway Maple, ACAS1=Silver Maple, ACAS2=Sugar Maple

From EXCEL file in Section SI.5. 


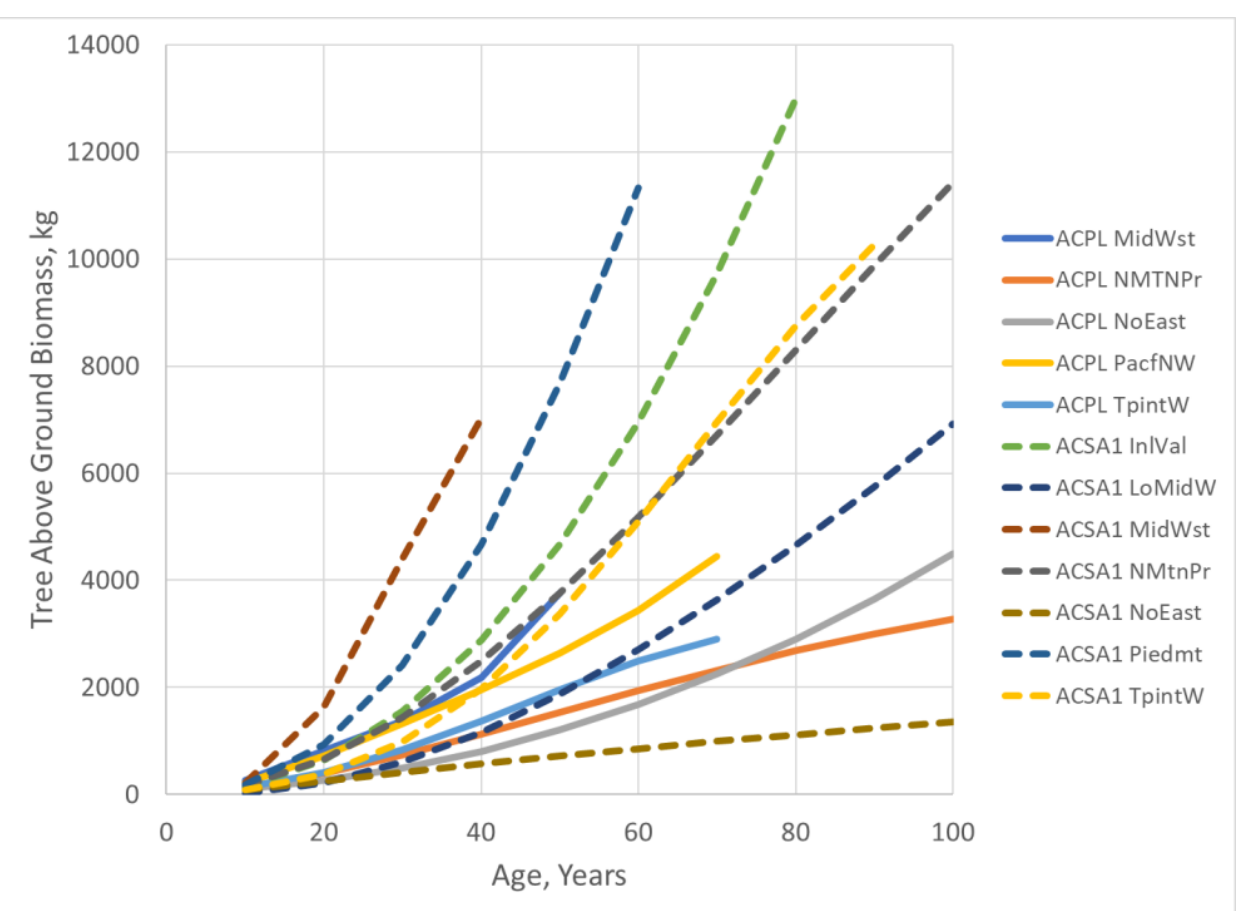

Fig. 5 Above ground biomass for some maple tree species in various regions of the U.S.

Data Source: McPherson, van Doorn, and Peper (2016) [39].

ACPL = Norway Maple, ACAS1=Silver Maple

From EXCEL file in Section SI.5.

The amount of space needed to bury all of the leaves is daunting when the weight of leaves required is compared to the current amount of municipal waste. However, this is what would be needed to get the world to Net Zero $\mathrm{CO}_{2}$ emissions. The amount required would of course be reduced by increased energy conservation, new solar and wind energy, the move of the transportation sector away from fossil fuels, and and new $\mathrm{CO}_{2}$ sequestration from large point sources.

Tree population is not distributed evenly around the world or even around the U.S. The U.S. has 228 billion trees, Brazil has 301 billion, Canada has 318 billion, and China has only 139 billion [41]. About $50 \%$ of Russia land area is covered by forests. U.S. trees are concentrated in the Northwest, East Cost, Southeast, and West Coast. Of course, sequestering leaves from all of these trees poses logistic problems. However, as noted above only a fraction is needed, especially if combined with other solutions.

The bottom line is there are solutions that can keep up with world $\mathrm{CO}_{2}$ generation. Some will not be easy or inexpensive, but there is hope. Everything is needed: energy conservation, the move to electric vehicles charged by power plants with $\mathrm{CO}_{2}$ sequestration, secure burial of municipal and yard waste, leaf sequestration, solar, wind, etc.

\section{Conclusions}

Carbon dioxide from fossil fuels is the main culprit of Global Warming. The problem is massive. 36 billion tons of $\mathrm{CO}_{2}$ are being released into the atmosphere each year. Finding a solution requires an understanding of where energy is produced and consumed and a proper understanding of the 
Carbon Cycle. While renewable energy is growing rapidly, it remains a very small part of overall energy. Other solutions are needed.

Bioethanol and biodiesel remain a small part of energy for transportation, which itself is less than $30 \%$ of overall energy consumed. Corn ethanol is traced through its Carbon Cycle. Biofuels would at best be sustainable, but are not, when energy for their production, and the stoichiometry of the fermentation reaction are considered. Two of the six carbons of glucose are converted to $\mathrm{CO}_{2}$, which most facilities release to the atmosphere before any useful work is done in an engine. Cellulosic ethanol promises cheap feedstock, but still faces a number of technical and economic challenges. This has slowed implementation. Only about $15 \mathrm{MM}$ gallons were produced in 2018 compared to $16,868 \mathrm{MM}$ gal of corn ethanol. That is the reality!

$\mathrm{CO}_{2}$ sequestration targets $\mathrm{CO}_{2}$ produced in large industrial furnaces, including those used to generate electric power. Industrial and power plant furnaces account for about half of $\mathrm{CO}_{2}$ generated. This is significant, but $\mathrm{CO}_{2}$ sequestration will not be a complete solution. The message is: We know how to do it, using variations of technologies that have been used for over 100 years. It is just going to cost money and scaleup is a major issue. Post-combustion capture can be retrofitted to the massive installed base of industrial furnaces, and thus, must be an essential part of solving the $\mathrm{CO}_{2}$ problem. Pre-combustion capture is a variation of a hydrogen plant, which produces a clean burning hydrogen product that can be burned in a combined cycle power plant to generate more electricity or exported for use in a refinery, chemical plant, or even for residential use (a hydrogen economy). Natural gas can be steam reformed, and coal can undergo partial oxidation. With $\mathrm{CO}_{2}$ sequestration, both natural gas and coal can become $\mathrm{CO}_{2}$-free fuels. The issue is that to date, few commercial-scale sequestration projects have been brought forward.

Biofuels and carbon dioxide sequestration can displace FUTURE $\mathrm{CO}_{2}$ from continued use of fossil fuels. The only way to reduce $\mathrm{CO}_{2}$ ALREADY in the atmosphere is to permanently sequester biomass. Rather than spending capital and energy to convert biomass to biofuels, permanent sequestration of biomass CARBON from tree leaves, crops, and municipal and yard waste is proposed. Theoretically, sequestration of only a fraction of the world's tree leaves can bring the world to Net Zero $\mathrm{CO}_{2}$ and without disruption of the underlying forests.

\section{Acknowledgements}

Amelse retired in 2017 after 35 years of R\&D at the Amoco Chemical Company (now BP Amoco Chemical Company Petrochemicals Technology, Naperville, IL USA), working mainly on paraxylene catalyst and process technology. He joined CICECO, Aveiro Institute of Materials, Department of Chemistry, University of Aveiro as Invited Principal Investigator to continue collaborating with Dr. Luis Mafra on the characterization of molecular sieve catalysts via Solid State NMR, work started while at BP. He also developed and taught a course on Petroleum Refining and Petrochemicals. He will begin a new 3-year year appointment with the Chemistry Department as Invited Associated Professor on August 1, 2020. This manuscript was developed between assignments with the university as an independent contributor.

Conflicts of Interest: The author declares no conflict of interest. 


\section{References}

1. EIA, U.S. Energy Information Authority (EIA), International Energy Outlook 2016, 2017.

2. BP (2019) Statistical Review of World Energy (2019). https://www.bp.com/en/global/corporate/news-andinsights/press-releases/bp-statistical-review-of-world-energy-2019.html Accessed May 19, 2020.

3. Valero (2018), “Basics of Refining and Optimization,” Feb. 20, 2018.http://phx.corporateir.net/External.File?item=UGFyZW50SUQ9NjI5NzYwfENoaWxkSUQ9MzMyODI0fFR5cGU9MQ==\&t=1

4. J. Gibbs, and M. Moore, Planet of the Humans, https://www.youtube.com/watch?v=Zk11vI-7czE, 2020. Accessed July 11, 2020.

5. Malhorta, R. (2015) SRI, A Cubic Mile of Oil: Realities and Options for Averting the Looming Global Energy Crisis, Thorium Energy Alliance Conference No. 7 https://www.youtube.com/watch?v=CpXG3zyg3gk Accessed May 19, 2020.

6. Wikipedia, Jan Baptist van Helmont, 2020. https://en.wikipedia.org/wiki/Jan Baptist van Helmont Accessed May 19, 2020.

7. Carson, J., How Much Carbon Can Soil Store I Fact Sheets I, 2020. http://www.soilquality.org.au/factsheets/how-much-carbon-can-soil-store Accessed May 25, 2020.

8. Alamy (2020) "The Carbon Cycle", 2020. https://www.alamy.com/search.html?qt=carbon\%20cycle\&imgt=0 Accessed May 19, 2020

9. Wikipedia, Photosynthesis, 2020. https://en.wikipedia.org/wiki/Photosynthesis Accessed May 21, 2020.

10. Encyclopedia Britannica, The Kyoto Protocol, 2020. https://www.britannica.com/event/Kyoto-Protocol Accessed May 19, 2020.

11. The Guardian, The rise of diesel in Europe: the impact on health and pollution, 2015. http://www.theguardian.com/environment/2015/sep/22/the-rise-diesel-in-europe-impact-on-healthpollution

12. EIA, Almost all U.S. gasoline is blended with $10 \%$ ethanol, 2016. https://www.eia.gov/todayinenergy/detail.php?id=26092 Accessed May 19, 2020.

13. EIA, Fuel Ethanol Supply and Disposition, 2019. http://www.eia.gov/dnav/pet/pet sum snd a epooxe mbbl m cur.htm Accessed May 19, 2020.

14. EIA, U.S. Exports of Crude Oil (Thousand Barrels per Day), 2019. http://tonto.eia.gov/dnav/pet/hist/LeafHandler.ashx?n=PET\&s=MCREXUS2\&f=M Accessed May 19, 2020.

15. EIA, U.S. Exports of Finished Motor Gasoline (Thousand Barrels), 2019. http://tonto.eia.gov/dnav/pet/hist/LeafHandler.ashx?n=PET\&s=MGFEXUS1\&f=M Accessed May 19, 2020.

16. Shifter, I. M. Vera, L. Diaz, E. Guzman, F. Ramos, and E. Lopez-Salinas, Environmental Implications on the Oxygenation of Gasoline with Ethanol in the Metropolitan Area of Mexico City, Env. Sci E Tech. 2001, 35 (10), 1893.

17. EIA, Monthly Biodiesel Production Report (2020), 2020. https://www.eia.gov/biofuels/biodiesel/production/ Accessed May 19, 2020. 
18. USDA, Feed Grains Data: Yearbook Tables, 2020. https://www.ers.usda.gov/data-products/feed-grainsdatabase/feed-grains-yearbook-tables.aspx Accessed May 19, 2020.

19. Ramirez-Cabral, N.Y.Z., L. Kumar, L. and F. Shabani, Global alterations in areas of suitability for maize production from climate change and using a mechanistic species distribution model (CLIMEX), Sci Rep., $2017,7,5910$.

20. EIA, U.S. Fuel Ethanol Plant Production Capacity, 2020. https://www.eia.gov/petroleum/ethanolcapacity/ Accessed May 19, 2020.

21. Latshaw, W.L., and E. C. Miller, E.C., Elemental Composition of the Corn Plant, J. Agricultural Research, 1924, Vol. 27, No. 11, p. 845-861.

22. Katzen, R., Moon, G.D., Jr., Kumana, J.D., US Patent No. 4,217,178, Distillation System for Motor Fuel Grade Anhydrous Ethanol, Aug. 12, 1980.

23. Kwiatkowski, J. R. (2006) A. J. McAloon, A.I., Taylor, F., Johnston, D.B., Modeling the process and costs of fuel ethanol production by the corn dry-grind process, Industrial Crops and Products 2006, 23 288-296.

24. Charles, D., NPR, Farm Subsidies Persist And Grow, Despite Talk Of Reform, 2016. https://www.npr.org/sections/thesalt/2016/02/01/465132866/farm-subsidies-persist-and-grow-despite-talkof-reform Accessed May 19, 2020.

25. Sandia Labs News Release, Biofuels can provide viable, sustainable solution to reducing petroleum dependence, say Sandia researchers, 2009.

https://share-ng.sandia.gov/news/resources/news releases/biofuels-can-provide-viable-sustainablesolution-to-reducing-petroleum-dependence-say-sandia-researchers/ Accessed May 19, 2020.

26. Retka Schill, S., Zero to 10 Million in 5 Years, Ethanol Producer Magazine, June 26, 2018. http://www.ethanolproducer.com/articles/15344/zero-to-10-million-in-5-years Accessed May 19, 2020.

27. Morris, G.L., U.S. Methanol On The Comeback, The American Oil and Gas Reporter, 2013. https://www.aogr.com/web-exclusives/exclusive-story/u.s.-methanol-on-the-comeback Accessed May 19, 2020.

28. USDA, U.S. Bioenergy Statistics, Table 6--Soybean oil supply, disappearance, and share, used for biodiesel, 2019. https://www.ers.usda.gov/data-products/us-bioenergy-statistics/us-bioenergystatistics/\#Feedstocks Accessed May 19, 2020.

29. Geoengineering Monitor, Direct Air Capture (Technology Fact Sheet), 2020. http://www.geoengineeringmonitor.org/2018/05/direct-air-capture/Accessed May 19, 2020.

30. Plant Barry CCS Demo (2011), http://www.zeroco2.no/projects/southern-company-ccs-demonstration Accessed May 19, 2020.

31. Kamiljo, T., Yonekawa, T., Inui, M., Hirata, T., Tsujiuchi, T., and Miyamoto, O., Deployment of World's Largest Post-combustion Carbon Capture Plant for Coal-fired Power Plants, Mitsubishi Heavy Industries Technical Review, Vol. 52 No. 1 , 2015. (March 2015).

32. Platt, J., Coal plant's carbon capture project passes first 100,000-ton milestone, MNN.com, 2012. https://www.mnn.com/earth-matters/wilderness-resources/stories/coal-plants-carbon-capture-projectpasses-first-100000 Accessed May 25, 2020. 
33. Dubin, K., Petra Nova is one of two carbon capture and sequestration power plants in the world, 2017. https://www.eia.gov/todayinenergy/detail.php?id=33552 Accessed May 21, 2020.

34. Jansen, D., Gazzani, Manzolini, M.G., van Dijk, E. and Carbo, M. (2015). International Journal of Greenhouse Gas Control 2015, 40, 167-187.

35. IEA Greenhouse Gas R\&D Programme (2005) “Building the Cost Curves for CO2 Storage - North America," Report No. 2005/3, February, 2005. https://ieaghg.org/docs/overviews/2005-3.pdf Accessed May 21, 2020.

36. IEA Greenhouse Gas R\&D Programme (2007) “Capturing $\mathrm{CO}_{2}$," https://ieaghg.org/docs/general publications/cocapture.pdf Accessed May 21, 2020.

37. Bagchi, A., Design, Construction and Monitoring of Landfills, $2^{\text {nd }}$ Ed., John Wiley \& Sons, Inc. (1994). ISBN: 0-471-30681-9

38. EPA, Facts and Figures about Materials, Waste and Recycling, 2020. https://www.epa.gov/facts-and-figures-about-materials-waste-and-recycling/national-overview-facts-andfigures-materials\#Landfilling Accessed May 22, 2020.

39. McPherson, E.G., van Doorn, N.S., and Peper, P.J., U.S. Forest Service General Tech. Report PSW-GTR-253, 2016.

40. Crowther, T., Glick, H., Covey, K. et al., Mapping tree density at a global scale, Nature, 2015, 525, $201-205$. https://doi.org/10.1038/nature14967

41. GreenBlizzard, How Many Trees in the U.S.?, 2016. http://greenblizzard.com/2015/09/28/how-many-trees-in-the-u-s/ Accessed May 22, 2020.

42. Ramirez, E.C., Johnston, D.B., McAloon, A.J., Yee, W., and Singh, V. Engineering process and cost model for a conventional corn wet milling facility." Industrial Crops and Products, 2008, 27, 91-97.

43. Ramirez, E.C., Johnston, D.B., McAloon, A.J., Yee, W., and Singh, V., “Enzymatic corn wet milling: engineering process and cost model," Biotechnology for Biofuels 2009, 2008. 2:2.

44. Davis, K.S., Corn Milling, Processing and Generation of Co-products, Minnesota Nutrition Conference, Minnesota Corn Growers Association, Technical Symposium, September 11, 2001.

45. Kwiatkowski, J. R., A. J. McAloon, A.I., Taylor, F., Johnston, D.B. Modeling the process and costs of fuel ethanol production by the corn dry-grind process, Industrial Crops and Products, 2006, 23 288-296.

46. Dale, R.T. (2006), and Tyner, W.E., Economics and Technical Analysis of Ethanol Dry Milling: Model Description, Depart. of Agricultural Economics, Purdue University, Staff Paper \# 06-04, April 24, 2006.

47. Humbird, D., et al., "Process Design and Economics for Biochemical Conversion of Lignocellulosic Biomass to Ethanol," NREL/TP-5100-47764, May 2011). https://www.nrel.gov/docs/fy11osti/47764.pdf Accessed May 19, 2020.

48. Switchgrass production for biomass (Research Brief \#51) | Center for Integrated Agricultural Systems, 2001. https://www.cias.wisc.edu/switchgrass-production-for-biomass/ Accessed May 3, 2020.

49. Kunzig, R., The End of Trash, National Geographic, p. 42, March 2020.

50. BioenergyAdvice.com, Wood Chips, 2020. https://www.bioenergyadvice.com/bio-fuels/wood-chips/ Accessed May 19, 2020. 
51. GE Reports The Wood Chips Are Down: GE Is Building A Massive Biomass Energy Plant In Belgium," 2020. https://www.ge.com/reports/the-wood-chips-are-down-ge-is-building-a-massive-biomass-energyplant-in-belgium/ Accessed May 19, 2020.

52. Flynn, B., North American Woodchip Export Supply," 9th International Woodfiber Conference DaNang, Vietnam, February 2017. https://events.risiinfo.com/wood-fiber/sites/default/files/presentations/2017/Flynn\%20Presentation.pdf Accessed May 20, 2020.

53. Customs News, Woodchip exports: Topping the world but not mastering the market, 2019. https://customsnews.vn/woodchip-exports-topping-the-world-but-not-mastering-the-market-11281.html Accessed May 20, 2020.

54. Vispute, T.P., Zhang, H. Sanna, A.,Xiao, R., and Huber, G.W., "Renewable Chemical Commodity Feedstocks from Integrated Catalytic Processing of Pyrolysis Oils," Science, 2010, Vol. 330, 1222-1227.

55. Lupton, S., Biomass Conversion to Heat, Power \& Fuels and Pyrolysis Oil Upgrading, Rapid Thermal Processing (RTP $\left.{ }^{\mathrm{TM}}\right)$, USDA-ARSTeleseminar Series on Chemical Conversion Technologies, October 11th, 2011. https://www.uop.com/processing-solutions/renewables/technology-for-biomass-conversion/ Accessed May 19, 2020.

56. Meyers , R.A. “Handbook of Petroleum Refining Processes,” 3rd Edition, McGraw-Hill, NY. 2004.

57. ExxonMobil, The Fat, Fit, Fantastic Green Machine, 2017. https://energyfactor.exxonmobil.com/sciencetechnology/fat-fit-algae-

biofuel/?utm source=google\&utm_medium $=$ cpc\&utm_campaign=XOM+\%7C+Corp $+\% 7 \mathrm{C}+\mathrm{ELH}+\% 7 \mathrm{C}+\mathrm{Traf}$ fic $+\% 7 \mathrm{C}+\mathrm{Brand}+\% 7 \mathrm{C}+\mathrm{Technology}+\% 7 \mathrm{C}+\mathrm{Biofuel}+\% 7 \mathrm{C}+\mathrm{Algae}+\% 7 \mathrm{C}+\mathrm{Exact} \& \mathrm{utm}$ content $=\mathrm{Brand}+\% 7 \mathrm{C}+\mathrm{Alga}$ e+\%7C+Biofuel+\%7C+ExxonMobil\&utm term=exxonmobil+algae+biofuel\&\&gclid=EAIaIQobChMInMv1vnZ6AIVUL7ACh250QKfEAAYASAAEgJg7vD BwE\&gclsrc=aw.ds

58. EIA, U.S. Energy Information Authority (EIA), Annual Energy Outlook 2020, 2020. https://www.eia.gov/outlooks/aeo/ Accessed May 19, 2020. 


\title{
SUPPLEMENTAL INPUT
}

\section{Achieving Net Zero Carbon Dioxide By Sequestering Biomass Carbon}

\author{
Jeffrey A. Amelse 1,2 \\ 1 CICECO, Aveiro Institute of Materials, Department of Chemistry, University of Aveiro, 3810-193 \\ Aveiro, Portugal; JAmelse@UA.Pt; \\ 2 Independent Contributor, Batavia, IL 60510 USA; AmelseJeff@Gmail.com \\ Received: date; Accepted: date; Published: date
}

\section{SI.1. Calculation of the Amount of Air With $400 \mathrm{ppmv} \mathrm{CO}_{2}$ Needed to Feed the Growth of 1 Acre of Corn}

The calculation is provided in the spreadsheet attached below. It takes about 0.85 acres of air from sea level to the end of the troposphere to feed the growth of 1 acre of corn.

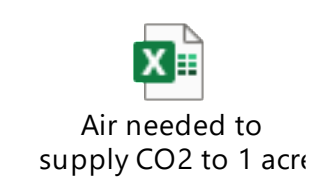

\section{SI.2. Process Description for Corn Ethanol Processes}

There are two major types of corn processing plants: Wet Mill and Dry Grind. Wet Mill plants predate bioethanol production. They are large, complex, and capital intensive, but in addition to having the ability to produce bioethanol, they produce a mix of high valued byproducts including high value corn oil, gluten animal feeds, and starch that can be hydrolyzed to sugar and fermented to bioethanol [42-44]. They can produce two animal feed byproducts, corn gluten feed having low protein content (21 wt\% typical) that can only be fed to ruminant animals such as cows, and corn gluten meal of high protein content (greater than $60 \mathrm{wt} \%$ ) that can be fed to chickens and pigs. However, most of the old Wet Mill plants prefer to divert the corn starch to enzymatic glucose production and then isomerize the glucose to fructose and make high fructose corn syrup sweeteners as a more valuable product than bioethanol.

Due to the scale and large capital required to make an economic Wet Mill corn plant, Dry Mill plants have become preferred for producing bioethanol [45-46]. Dry Mill plants are less complex, require much less capital, and are compact, such that many of the Dry Grind plants are located remotely in the middle of corn fields. A schematic of a Dry Grind bioethanol plant is shown in Fig. SI6.

Corn is ground in a hammermill to break the pericarp. The milled corn is slurried with water and cooked to soften and release the starch from the gluten proteins holding the starch granules together. The cooked mash then undergoes enzymatic liquefaction to depolymerize the starch and release the glucose. After liquefaction, the sugars are fermented to form a "beer" containing about 10-15 vol\% ethanol. Water must be removed to meet a specification of less than $1 \mathrm{vol} \%$ water. Removing that water is very energy intensive.

Dry grind plants do not have the flexibility of byproducts of Wet Mill plants. In fact, the original Dry Grind process produces only two salable products: bioethanol and a low protein animal feed 
(DDGS $=$ Distiller's Dry Grain Solids or DWGS $=$ Distiller's Wet Grain Solids). DWGS is obviously less valuable due to its moisture content. (There are now Modified Dry Grind plants that produce some more valuable byproducts, but less than Wet Mills.) The protein content of DDGS is so low that it can only be fed to ruminant animals (cows). It cannot be fed neat to pigs and chickens. (Oh, for the days of prime tender corn-fed beef!)

A typical Dry Grind ethanol plant converts one standard bushel of corn (defined as $56 \mathrm{lb}$ ) into $2.7 \mathrm{gal}$ $(17.8 \mathrm{lb})$ of ethanol and $15 \mathrm{lb}$ of DDGS.

\section{SI.3. Cellulosic Ethanol}

A dated study estimated capital and production costs for a cellulosic ethanol plant [47]. The cost challenge as of 2011 was:

Current Ethanol Sales Price: $\$ 2.15$

Ethanol Yield $\quad 79 \mathrm{gal} /$ ton (76\% efficiency)

Ethanol Production Volume 61.0 MM gal/yr

Capital Investment $\$ 423$ million

TCI per annual gal $\$ 6.92$

The TCI of $\$ 6.92$ was 3.2 times the then current sales price of corn ethanol.

Cellulose is a polymer of sugars that has a different structure than starch as shown in Fig. SI8. In starch, the $\mathrm{CH}_{2} \mathrm{OH}$ groups of the monomers are on the same side of 6-member ring. In cellulose, they are on the opposite side of the rings. This leads to cross linkage, which leads to dense packing of the polymer chains as shown in Fig. SI9, making cellulose insoluble in water, and attack by enzymes to unzip the polymers and release the sugar monomers slow. Special, high cost enzymes are needed. Cellulose also incorporates pentose monomers in addition to glucose monomers. A cellulose pretreatment step is required ahead of fermentation. Pretreatment may involve treatment with strong or dilute acids, ammonia, or alkaline peroxides. Thus, the pretreatment step may be corrosive, requiring high cost materials of construction, such as stainless steel, instead of low-cost carbon steel. The chemicals used in the pretreatment step may convert the pentose monomers to furans, which may inhibit enzyme attack, further slowing the kinetics. Slow kinetics means large pretreatment vessels, further increasing the cost of the pretreatment step. Thus, the pretreatment step may add one third to the capital cost ahead of fermentation which currently makes cellulosic ethanol less economic than corn ethanol, which already struggles economically.

Plant biomass also includes lignin in addition to cellulose, which becomes a byproduct and lowers ethanol yield based on total biomass carbons. Byproduct lignin yield is high, and lignin becomes a nuisance byproduct (Note the estimated low $76 \%$ yield above).

Thus, while cellulose may be a cheaper feedstock than corn, total cost of production must be considered, including capital charge and operating costs. The higher cost of capital, lower yield, and lignin formation currently outweigh the cheaper feedstock cost.

Again, cost should not be a deterrent to the development of a technology that can help displace future fossil fuels with renewable fuels. However, cost has led to slow development and implementation. Continued research on cellulosic ethanol is justified at the moment while gasoline vehicles continue to dominate. A breakthrough in better enzymes would help. However, a better solution is a move away from hydrocarbon vehicles. 
Instead of spending money on high capital cost, high cost enzymes, and other operating costs to convert cellulose to ethanol, sequestration of the biomass may be a more effective way to remove biomass carbon from the Carbon Cycle. High yield crops, such as switchgrass, which can be grown where corn cannot, should be considered for this operation. Switchgrass has an average yield of 2.3 tons per acre, and yield can be as high as 6-7 tons per acre [48]. Switchgrass has been suggested as a renewable energy source that can be mixed with coal and burned to generate electricity. This would make the switchgrass carbons renewable. However, $\mathrm{CO}_{2}$ from the burned switchgrass would still enter the atmosphere. A more effective way of removing $\mathrm{CO}_{2}$ ALREADY in the atmosphere would be secure burial of the switchgrass biomass.

One issue may be how to pass the cost on to society of biomass sequestration. Psychologically, it is easier for the public to bear the cost of bioethanol, when they are getting something tangible to put in their gas tanks. Getting society to bear the cost of putting biomass into the ground forever is going to be more of a challenge. Perhaps the fairest way is to charge the cost of sequestration as a carbon tax on industries generating $\mathrm{CO}_{2}$.

\section{SI.4. Other Routes for Biomass to Fuels}

Some other routes for converting biomass to fuels will be discussed in this section.

What was the first use of biomass for fuel? The campfire. Now most developed countries use other fuels for home heating, such as natural gas, propane, or fuel oil. Why? Because gathering firewood is labor intensive. Not everyone has access to wood. Fireplaces are inefficient and create smoke and soot. This simple example illustrates that just because there is a solution to a problem, it may not necessarily be the best or most economical solution. As noted, economics should not prevent consideration of solutions for solving global warming. However, it can influence which technologies will dominate in a free marketplace.

Converting biomass to biofuels is inefficient due to parasitic energy loss. In the case of cellulosic biomass to bioethanol will incur yield loss to $\mathrm{CO}_{2}$ via the fermentation reaction, and yield loss to byproducts, such as lignin, and other challenges. Rather than spending capital and energy converting biomass to biofuels, simply burning the biomass to produce power may be a more costeffective solution. Indeed, this is being commercialized now on a large scale.

The March, 2020 issue of National Geographic has an excellent article (well worth a read) titled "The End of Trash" [49]. The article describes an incinerator in Denmark that converts 534,600 tons of municipal waste a year to produce electricity for 30,000 homes and to heat 72,000 . Thus, the carbon in this waste becomes renewable, and displaces FUTURE $\mathrm{CO}_{2}$ from fossil fuels used to generate energy for this heating and electricity consumption. The burning of the waste generates $\mathrm{CO}_{2}$, albeit renewable $\mathrm{CO}_{2}$. From the standpoint of the carbon cycle, this material would have eventually decomposed and released its carbon back to the atmosphere, so the net gain is the displacement of fossil fuels. $\mathrm{CO}_{2}$ from the burning of waste still enters the atmosphere. There are also issues with feeding non-organics to furnaces.

This article describes and calls for other interesting steps that can or should be taken towards a sustainable economy. The need to reduce food waste, and the reuse of used clothing are examples. Wood chips are now being used as a replacement for coal in power plants [50-52]. This does replace FUTURE $\mathrm{CO}_{2}$ produced from fossil fuels with a renewable fuel source. 1497 dry metric tonnes of wood chips were exported from the U.S in 2016, representing the equivalent of 2418 U.S. short tons 
of $\mathrm{CO}_{2}$ [53]. However, some argue that these plants can have a number of draw backs including clearing U.S. forests for export, and low power plant efficiency. Numerous power plants based on wood chips or biomass have sprug up across the U.S. For an eye opening discussion of some of the issues surrounding them, see the movie by J. Gibbs and M. Moore [4]. Of course, like coal, wood chips can be gasified to form synthesis gas. But, as proposed here, perhaps it is better to remove that biomass from the Carbon Cycle and bury it securely.

Professor Huber's group at the University of Massachusetts developed fast pyrolysis of biomass as a process for concerting biomass to a bio-oil that can be used as feedstock to produce fuels and chemicals [54]. In the lab, biomass was heated very rapidly using a Pt wire heating medium to produce the bio-oil. The reaction is over in seconds. When I saw a lecture by Prof. Huber, my first reaction was how are you going to do that on a commercial scale. Leave it to man's ingenuity. UOP called upon its knowledge of refinery Fluid catalytic cracking (FCC) to develop an analogous process, its Rapid Thermal Processing (RTPTM) process [55]. A description of that process is provided below. In a Refinery Fluid Catalytic Cracking (FCC) unit, ultrastable zeolite-Y (USY) catalyst is mixed with gas oil and sent up a tube (a riser reactor), where large molecules are cracked to smaller gasoline or diesel range molecules [56]. Reaction takes place at high temperature (over $500 \mathrm{C}$ ) and is highly endothermic. Thus, an ingenious way to heat the feed and catalyst was needed. Liquid feed is preheated by conventional feed/effluent heat exchange followed by supplemental heating in a furnace. The catalyst deactivates very quickly and is essentially dead after it exits the riser due to carbonaceous coke laydown. The coked catalyst is directed to a regenerator where it is fluidized by compressed air. The air burns the coke forming $\mathrm{CO}_{2}$ in a highly exothermic reaction. This heats the regenerated catalyst to a temperature above its entrance temperature. When blended with preheated feed, the right temperature for reaction is achieved. Heat from the burning of coke reduces heat needed to preheat the gas oil feed. The heat balance between endothermic catalytic cracking and exothermic coke burn is critical to FCC unit design and operation.

In the UOP RTPTM process, the FCC catalyst is replaced by sand. Like FCC, the RTPTM process produces a lot of coke. Thus, like FCC there is a balance between the endothermic fast pyrolysis and regenerator. The bio-oil produced is full of oxygenates including acids, so it is very corrosive and unstable, requiring expensive materials of construction. The bio-oil must be hydrotreated to reduce oxygenates to be useful in downstream processes. UOP claims yield of bio-oil is high, but that means around $70 \%$. Some gas is generated, but also some heavy oil, which is a nuisance byproduct. UOP has proposed using the oil as fuel for generating electricity. Heating value of the oil is only about half that of conventional No. 2 fuel oil. UOP working with partners has developed special burner tips. In the end, UOP claims the economics can compete favorably against No. 2 fuel oil.

Algae has been touted as having a high oil content that can be used to produce biodiesel. Exxon Mobil has partnered with Synthetic Genomics, Inc. (SGI) to produce an algae strain that has about $40 \mathrm{wt} \%$ oil [57]. Algae is said to offer the following advantages. It can be grown on non-arable land. It is a non-food biomass source. One may envision integrated power plant/algae biodiesel plants that grow algae from $\mathrm{CO}_{2}$ in power plant furnace exhaust. However, the process looks complex and expensive and scale-up to appreciable size appears to be a long way away. Also, while $40 \%$ oil content is high compared to the $18-19 \mathrm{wt} \%$ of oil in soybeans, what do you do with the balance of the algae after the oil is extracted? 
In order to pull more carbon from the atmosphere or flue gas, it might be better to grow algae, slurry it with water, and sequester the whole of the algae biomass by pumping it into spent oil wells or other reservoirs.

\section{SI.5. Process Description for a Methane Steam Reforming Hydrogen Plant} Refer to Fig. SI12.

Feed gas is preheated and pretreated to remove sulfur. For natural gas with low levels of sulfur, sulfur may be removed by passage through a bed of zinc oxide where the sulfur is converted to zinc sulfate. Feed gases with higher amounts of sulfur (coal, for example) require a hydrotreater.

The pretreated gas is mixed with steam (and some recycled hydrogen product) and reformed over a catalyst at high temperature. For typical smaller size hydrogen plants, the reforming "reactor" is catalyst packed right into furnace tubes. The feed is first preheated by heat exchange with hot flue gas. Heat is recovered from the hot flue gas by generating steam. The hot effluent from the steam reforming reactor is cooled and passed to water-gas shift reactors. Equilibrium conversion to $\mathrm{CO}_{2}$ and $\mathrm{H}_{2}$ in the water-gas shift reactors is favored by low temperature. Water-gas shift is usually done in two steps. A first high temperature shift reactor is used to provide faster reaction kinetics. A second low temperature shift reactor is used to favor higher equilibrium conversion.

$\mathrm{CO}_{2}$ is removed from the shift reactors effluent by either absorption in an amine solution, followed by stripping of the $\mathrm{CO}_{2}$ product by distillation, which requires steam, or by adsorption on a molecular sieve bed followed by desorption by pressure swing or temperature swing.

The hydrogen atoms in the methane are converted to water. If absorption is used to separate the $\mathrm{CO}_{2}$, the amine will be circulated to the absorber as a water solution, but the water from the combustion will dilute the amine and must therefore be removed from the process at the same rate it is formed by taking a drag stream off the $\mathrm{CO}_{2}$ stripping tower or a separate distillation step (not shown).

The flue gas from the furnaces is hot. Absorption is endothermic, and thus is favored by lower temperature. The flue gas must first be cooled in a cooling or quench tower. This tower also knocks out some of the water of combustion down to its vapor pressure at the temperature at which this tower operates. A water pump around may be used as shown. The absorber itself must be cooled by cooling water. The absorber would typically have two sections as shown: a lower section where a rich amine solution is sent to the top of the section and this section acts as a true stripper. The upper section would include a water pump around with further cooling to reduce the concentration of amine in the product gas stripped of $\mathrm{CO}_{2}$.

The rich amine solution (rich in $\mathrm{CO}_{2}$ but diluted by remaining water from combustion) exits the bottom of the tower is pumped through a preheat feed/effluent exchanger to the $\mathrm{CO}_{2}$ stripping tower. $\mathrm{CO}_{2}$ product is taken overhead, compressed to liquify, and sent to storage. The lean amine solution stripped of $\mathrm{CO}_{2}$ is recycled back to the absorber.

The air to large industrial furnaces is controlled by dampers. Large furnaces typically run at $2-4 \%$ excess oxygen (and of course 79/21 time more nitrogen). It is most economical to run at a low excess oxygen since heat is absorbed by the excess oxygen and excess nitrogen and is wasted by venting the hot flue gas. However, it cannot run too low, because that can starve the flame, causing soot formation (black stack gas exiting the furnace) and could cause safety issues during upsets that would extinguish the flame with fuel still fed to the furnace. Oxygen can cause degradation of the amine 
absorbent or solid adsorbent. Solid adsorbents are being investigated as an alternative to absorption to save energy from the amine stripping step.

Note that steam is generated in multiple places in the process. That steam can be used to turn turbines to generate electricity in a combined cycle power plant. $\mathrm{CO}_{2}$ is removed from the watergas shift reactor effluent, compressed to liquify, and sent to storage. Thus, a clean high purity hydrogen product is produced. In a combined cycle power plant, the hydrogen (the PreCombustion fuel product) can be used to produce more steam and more power, or it can be exported for use in a refinery or chemical plant or elsewhere (the basis for a hydrogen economy).

\section{SI.6. OK, So We Have Captured $\mathrm{CO}_{2}$, Now What Do We Do With It?}

Now that $\mathrm{CO}_{2}$ has been captured and liquified, we need to find a home for this product. The $\mathrm{CO}_{2}$ can be compressed, liquified and transported to its final destination. $\mathrm{CO}_{2}$ transportation by pipeline is proven technology. The first increments of captured $\mathrm{CO}_{2}$ have commercial value for the soft drink and other industries, and for use in tertiary oil recovery. Fig. SI15 provides IEA projected cost for $\mathrm{CO}_{2}$ on-shore storage as a function of cumulative $\mathrm{CO}_{2}$ captured [35]. Cost is negative for the first 6$7 \mathrm{MMtons} / \mathrm{yr} \mathrm{CO}_{2}$ captured due to its value to the commercial markets (beverages, tertiary oil recovery, etc.) Beyond that there is a positive cost to transport and sequester $\mathrm{CO}_{2}$ underground. Cost remains flat at about \$12-14 per MMton/yr up to about $28 \mathrm{MM}$ tons, and then rises very rapidly. Thus, it is not practical to get it all. Fig. SI16 shows that going after about the first 600 of around 2000 large point sources of $\mathrm{CO}_{2}$ in the North America could capture about $80 \%$ from large point sources [35]. However, note that this would only remove about $28 \mathrm{MM}$ tons of $\mathrm{CO}_{2}$. We need to remove $3600 \mathrm{MM}$ tons/yr just to keep up with global production. Thus, other solutions are needed. So where do we put all of the sequestered $\mathrm{CO}_{2}$ ? It has been proposed to store it underground in spent oil wells, or in geological formations, such as sections of spent underground salt mines. Fig. SI17 shows that there are potential storage locations near the 500 largest point sources [35]. Overlap of location of large point sources and potential locations for storage is good, indicating that liquified $\mathrm{CO}_{2}$ might not have to be transported very far. Note that some bioethanol plants make the list of 500 largest point sources. Technology for to capping underground oil wells is well known. The challenge is how to utilize underground caverns to store a volatile gas at atmospheric pressure. (There may be a better use for these locations, such as biomass sequestration.)

\section{SI.7. EXCEL files that Calculate Urban Tree Growth Parameters in 10 Year Increments}

EXCEL files that calculate tree growth parameters from the allometric equations provided in the USDA report [39].

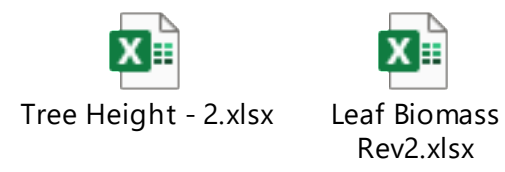




\section{SUPPLEMENTAL INFORMATION FIGURES}

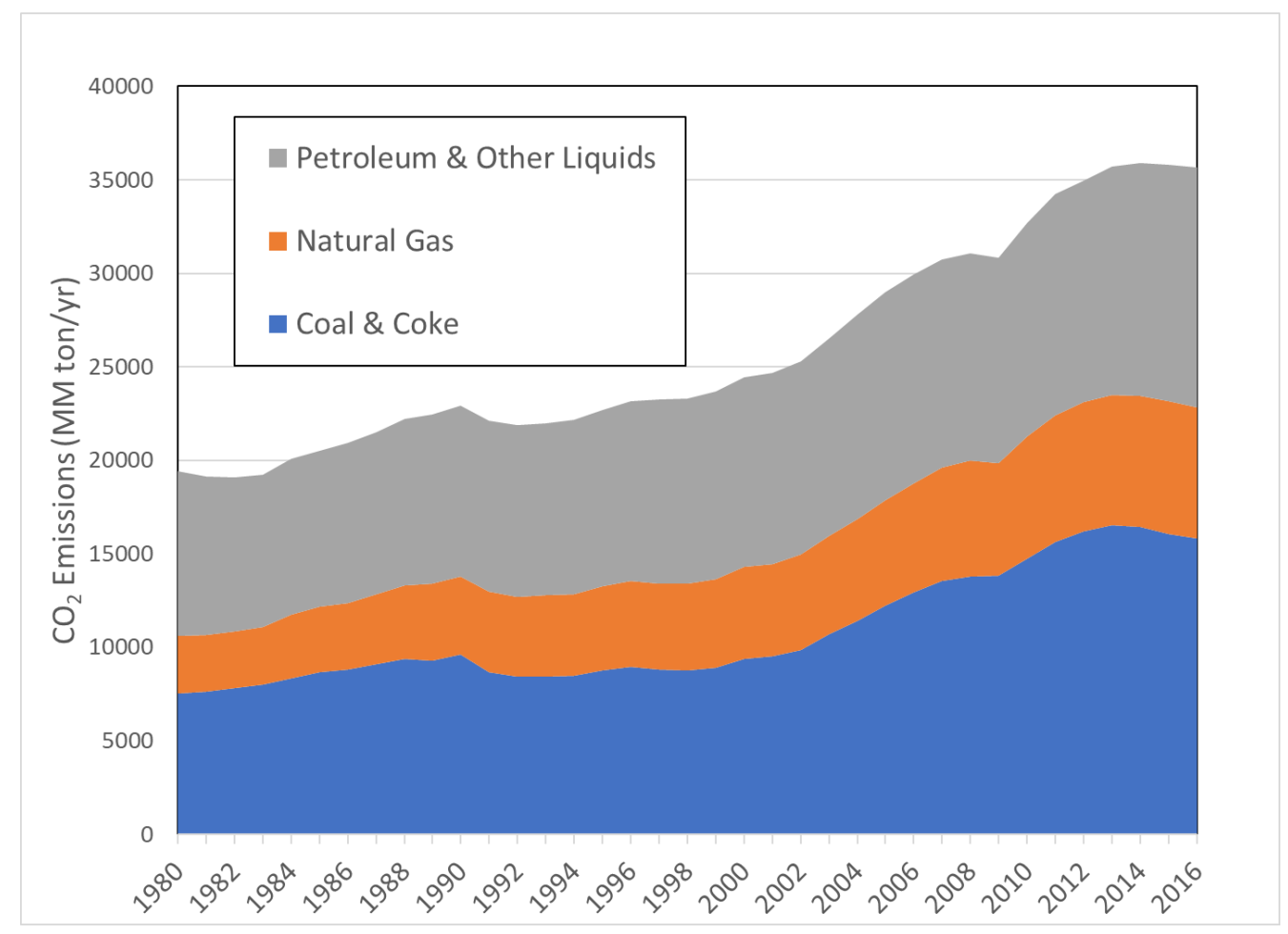

Fig. SI1. Magnitude and Source of CO2 Emissions

Data Source (EIA, 2017). All Rights Reserved. [1]

\section{6}

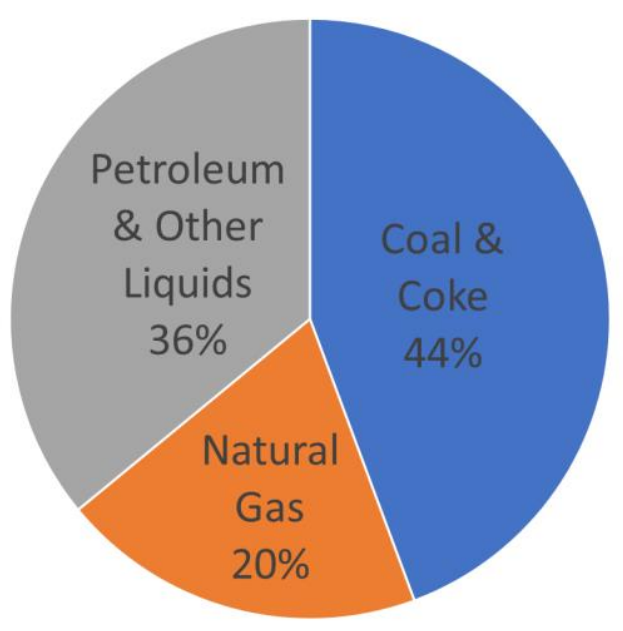

Fig. SI2. Breakdown of $2016 \mathrm{CO}_{2}$ Emissions By Fuel Source

Data Source (EIA, 2017). All Rights Reserved. [1] 


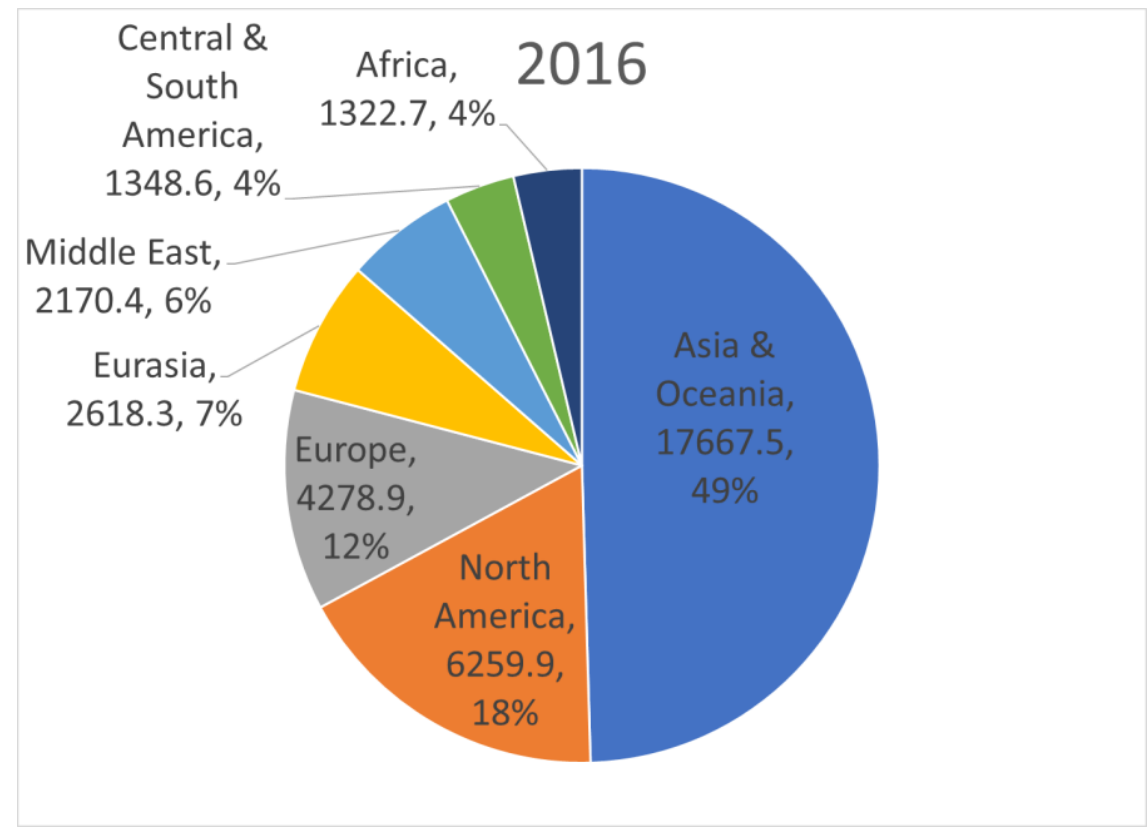

Fig. SI3. $2016 \mathrm{CO}_{2}$ Emissions by Region

Data Source (EIA, 2017). All Rights Reserved. [1]

Coal demand in select countries/regions in 2000, 2017, and 2023 3000

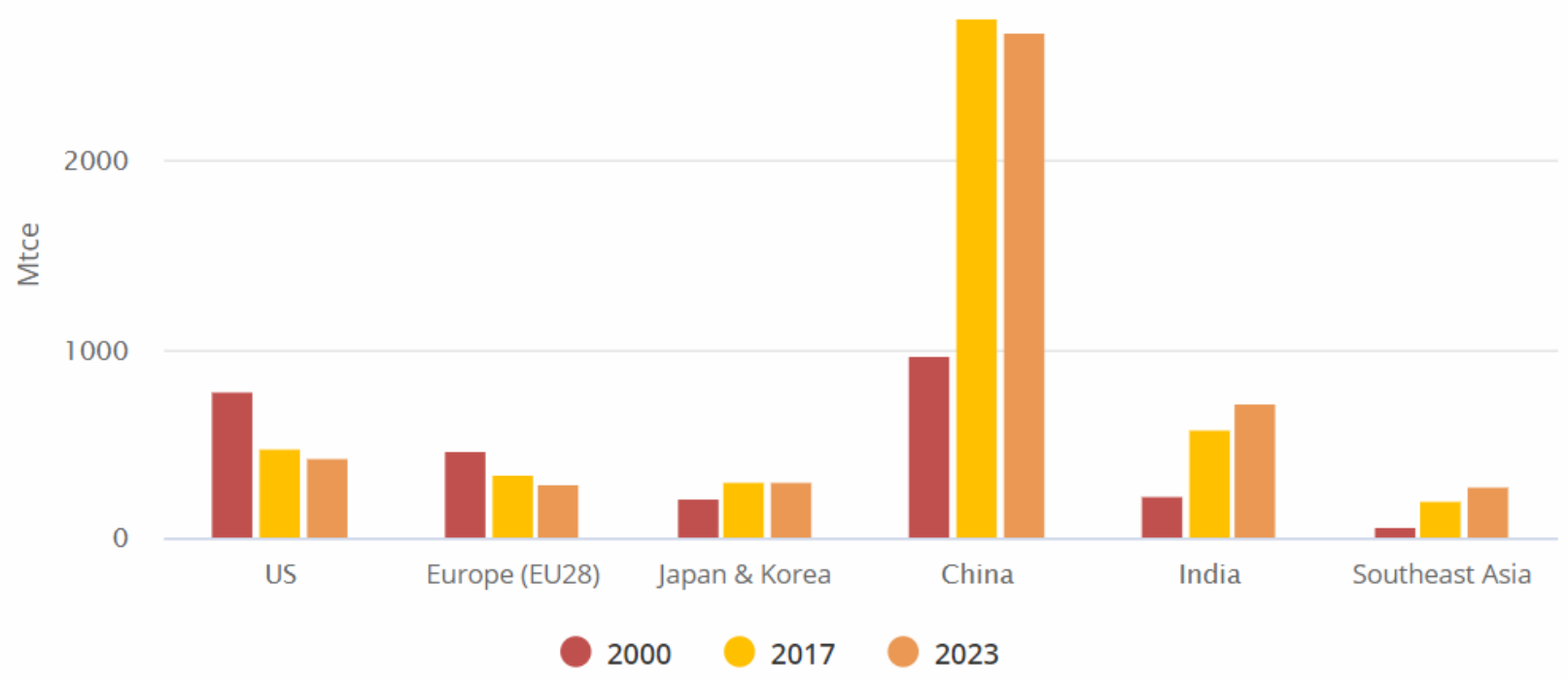

Fig. SI4. Coal demand in select countries/regions in 2000, 2017, and 2023.

Data Source: EIA (2017). All Rights Reserved. [1] 


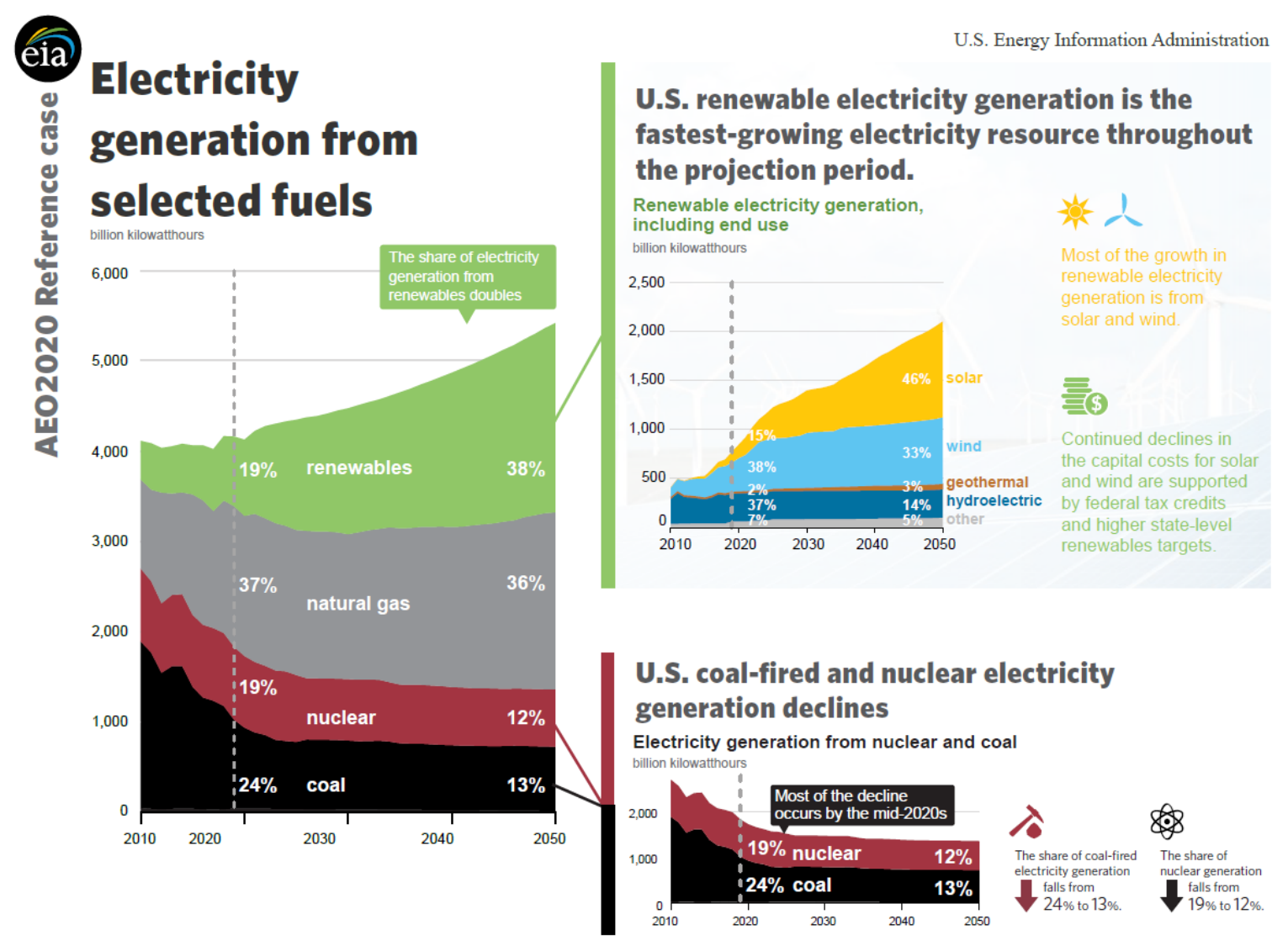

Source: U.S. Energy Information Administration, Annual Energy Outlook 2020 (AEO2020) Reference case

Fig. SI5. Electricity generation from selected fuels and breakdown of where the future growth in renewables is projected to come from

Source: (EIA, 2020). All Rights Reserved. [58]
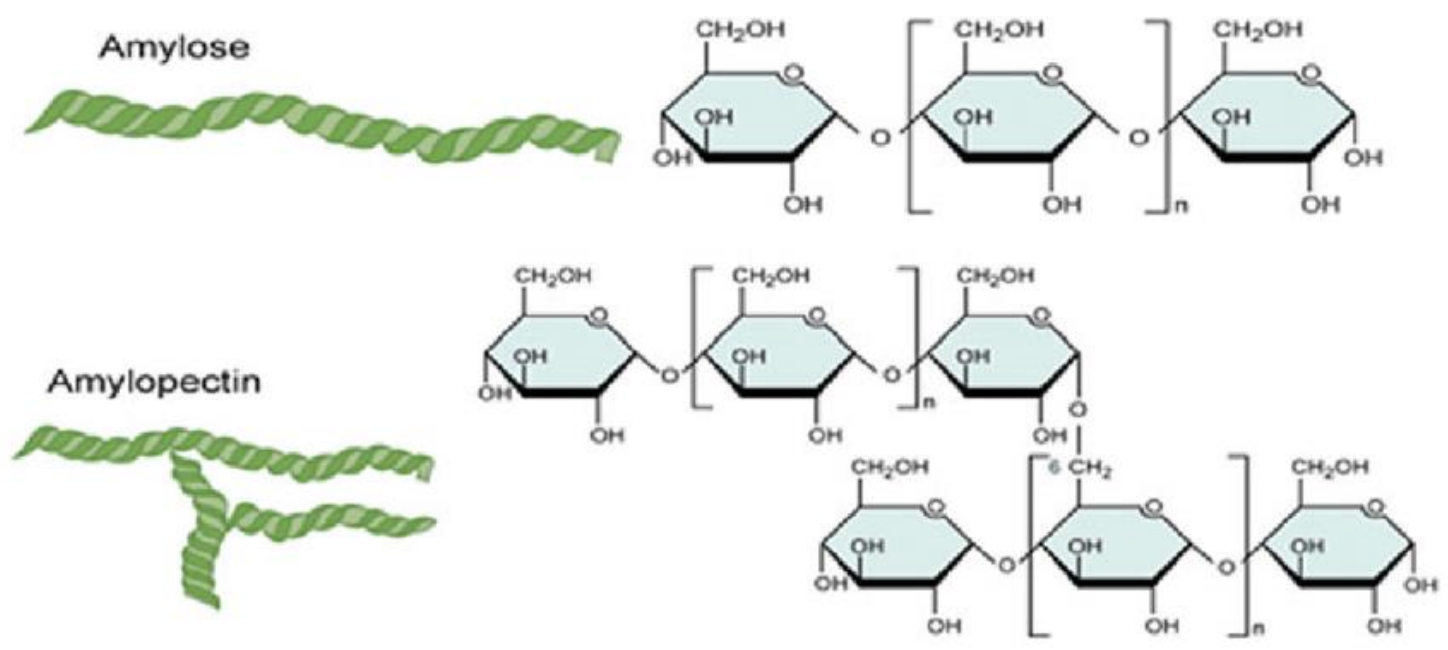

Fig. SI6. Amylose and Amylpectin polymers of glucose in corn starch 


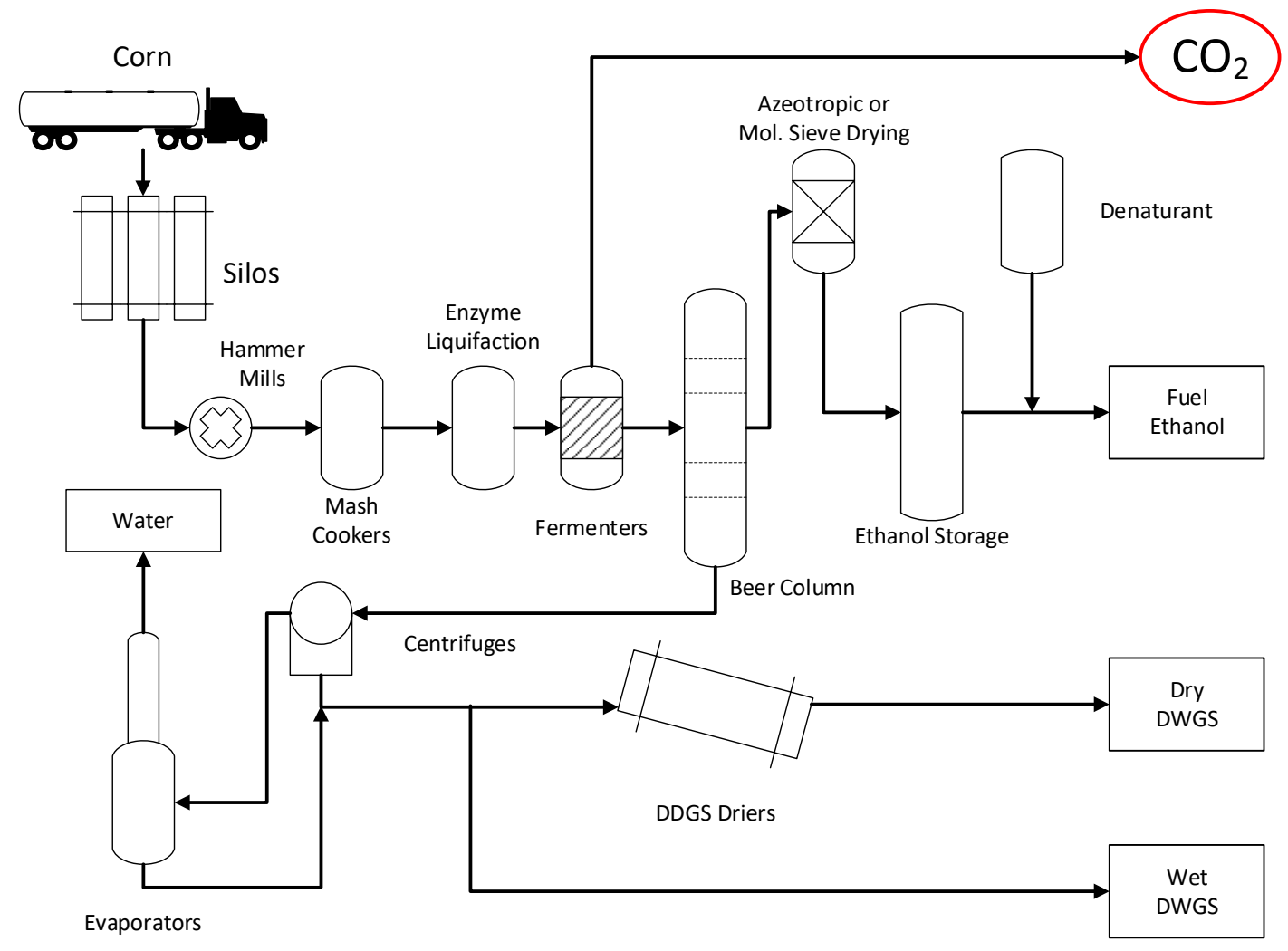

Fig. SI7. A Dry Grind Corn Ethanol Plant
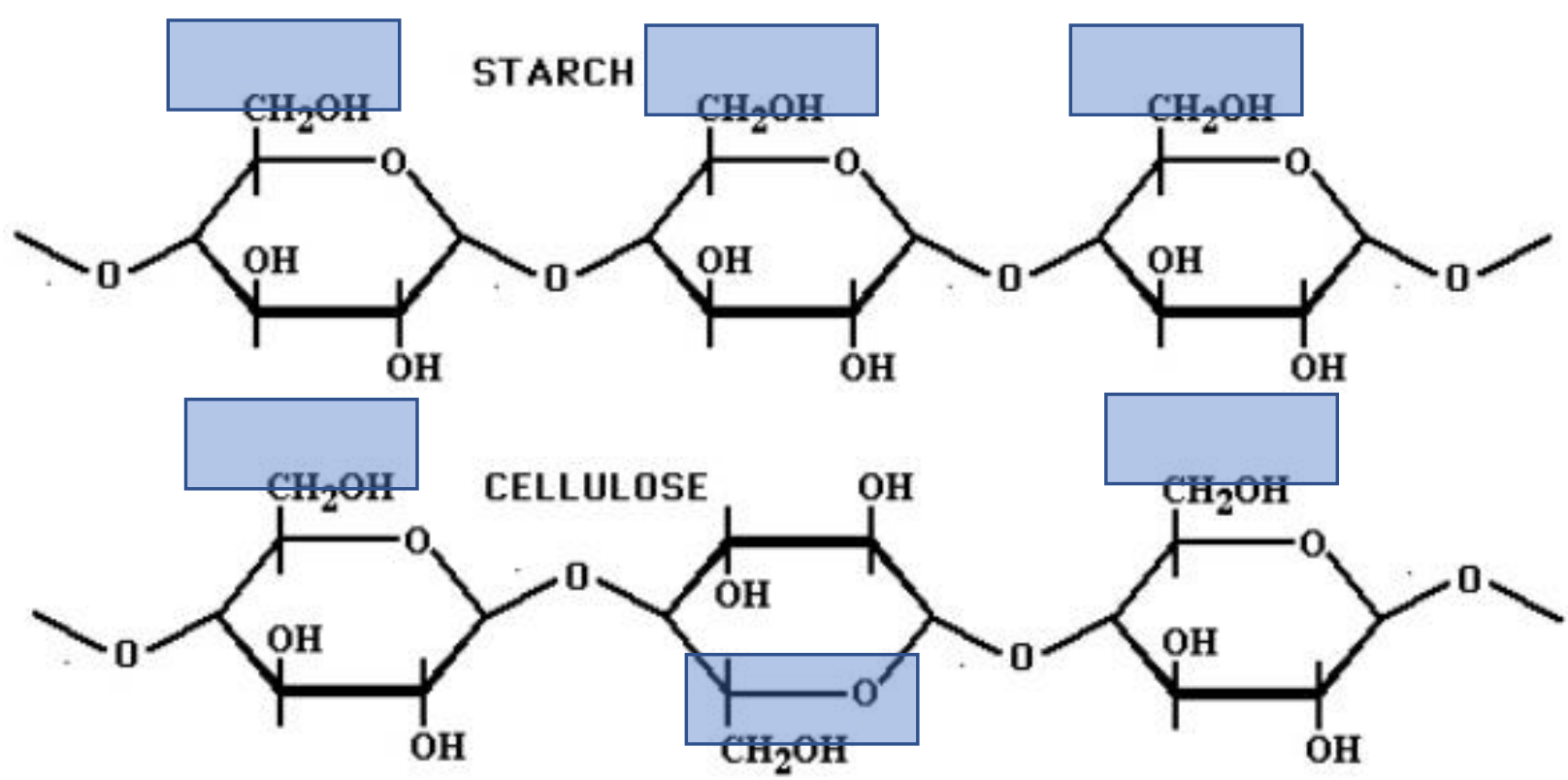

Fig SI8. The difference between starch and cellulose 


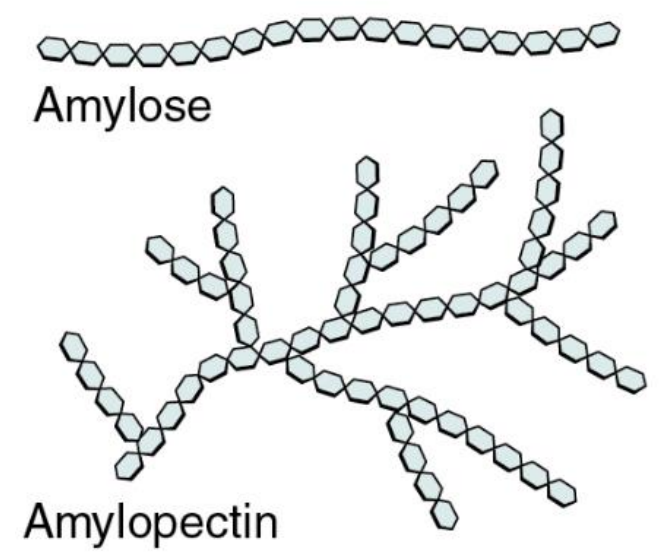

\section{Starch}

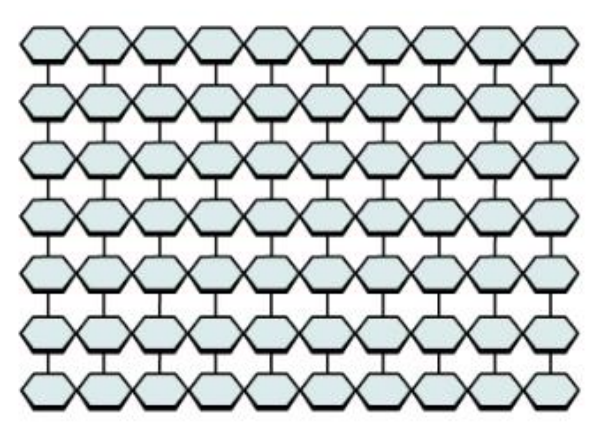

Cellulose (fiber)

Fig SI9. The difference between starch and cellulose packing structures

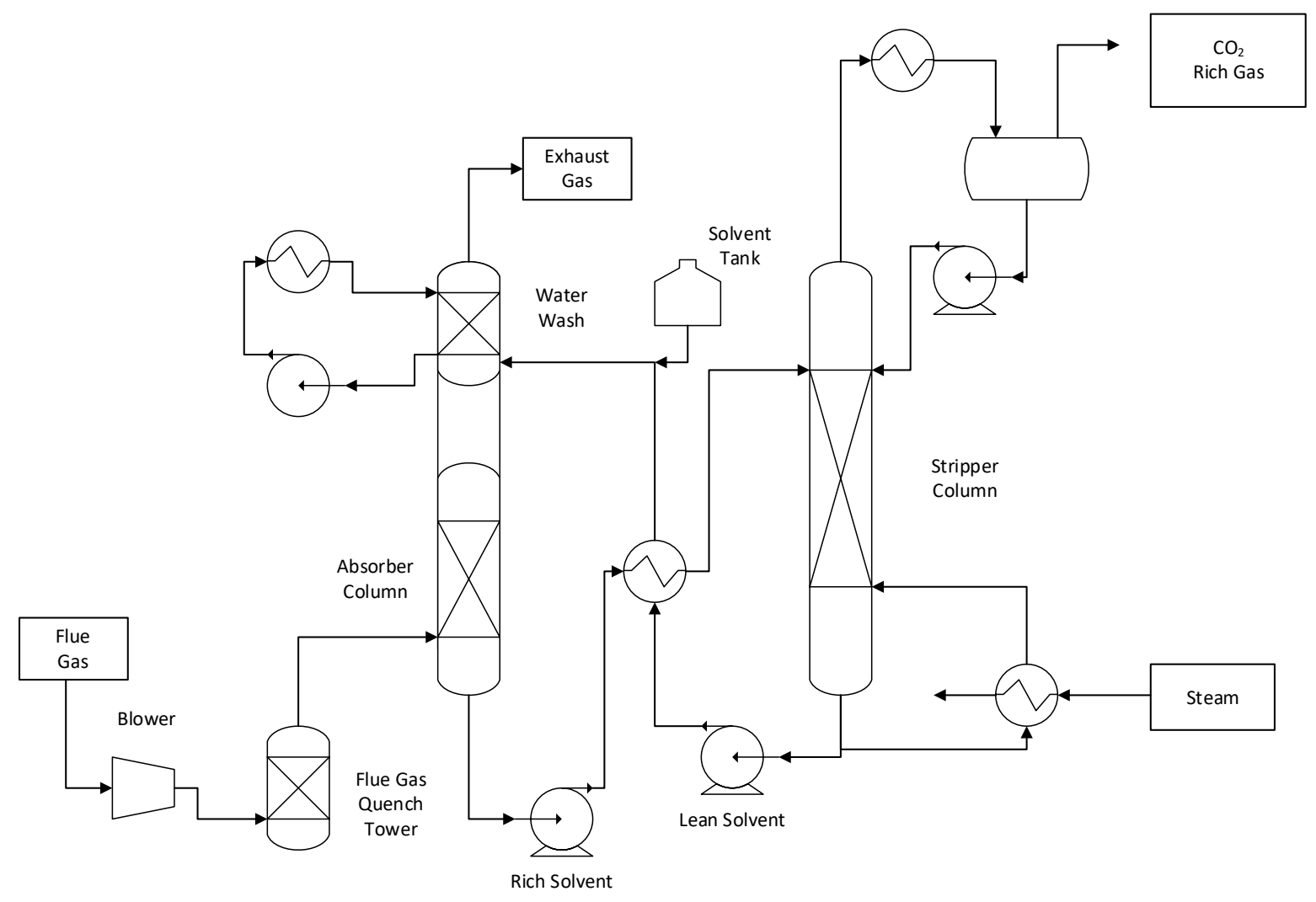

Fig. SI10 The post-combustion $\mathrm{CO}_{2}$ capture process 


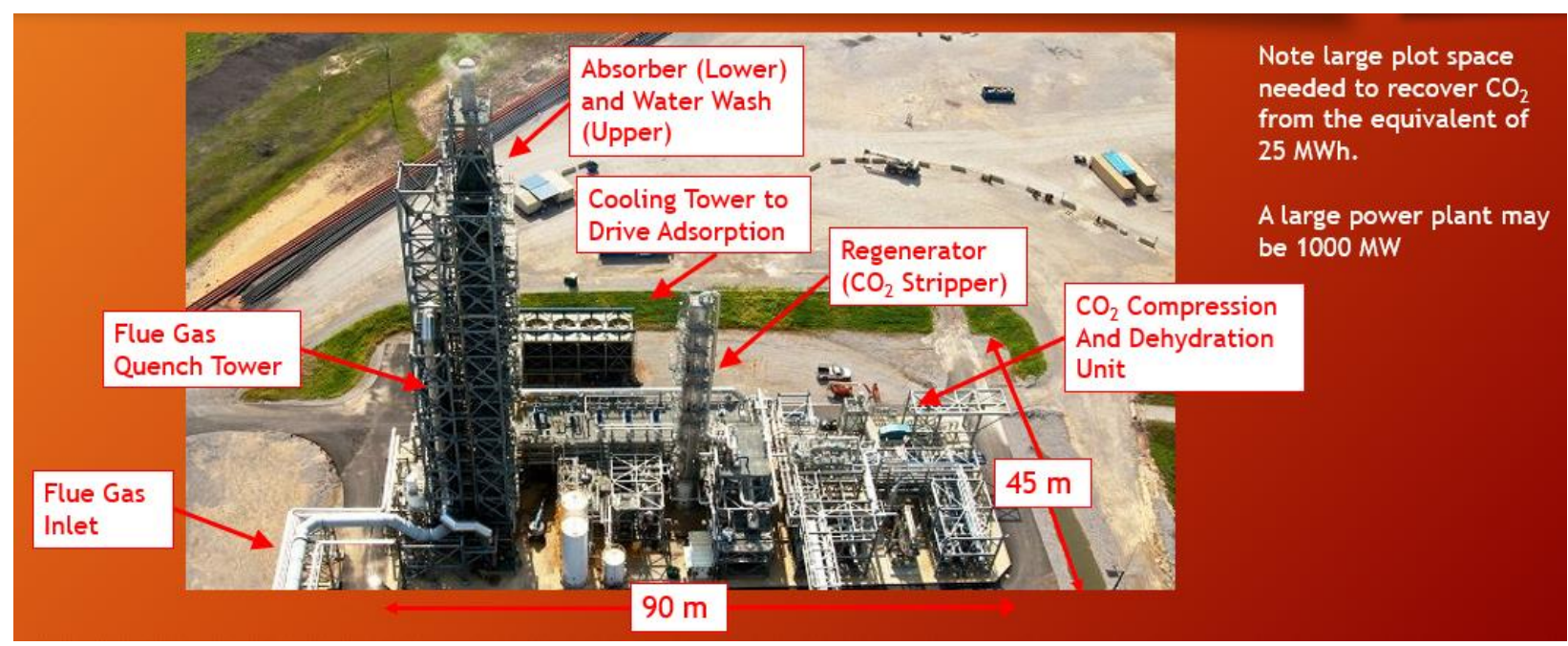

Fig. SI11. Alabama Power Plant Barry CO2 Capture Demonstration Unit Showing the Scale [30-32].

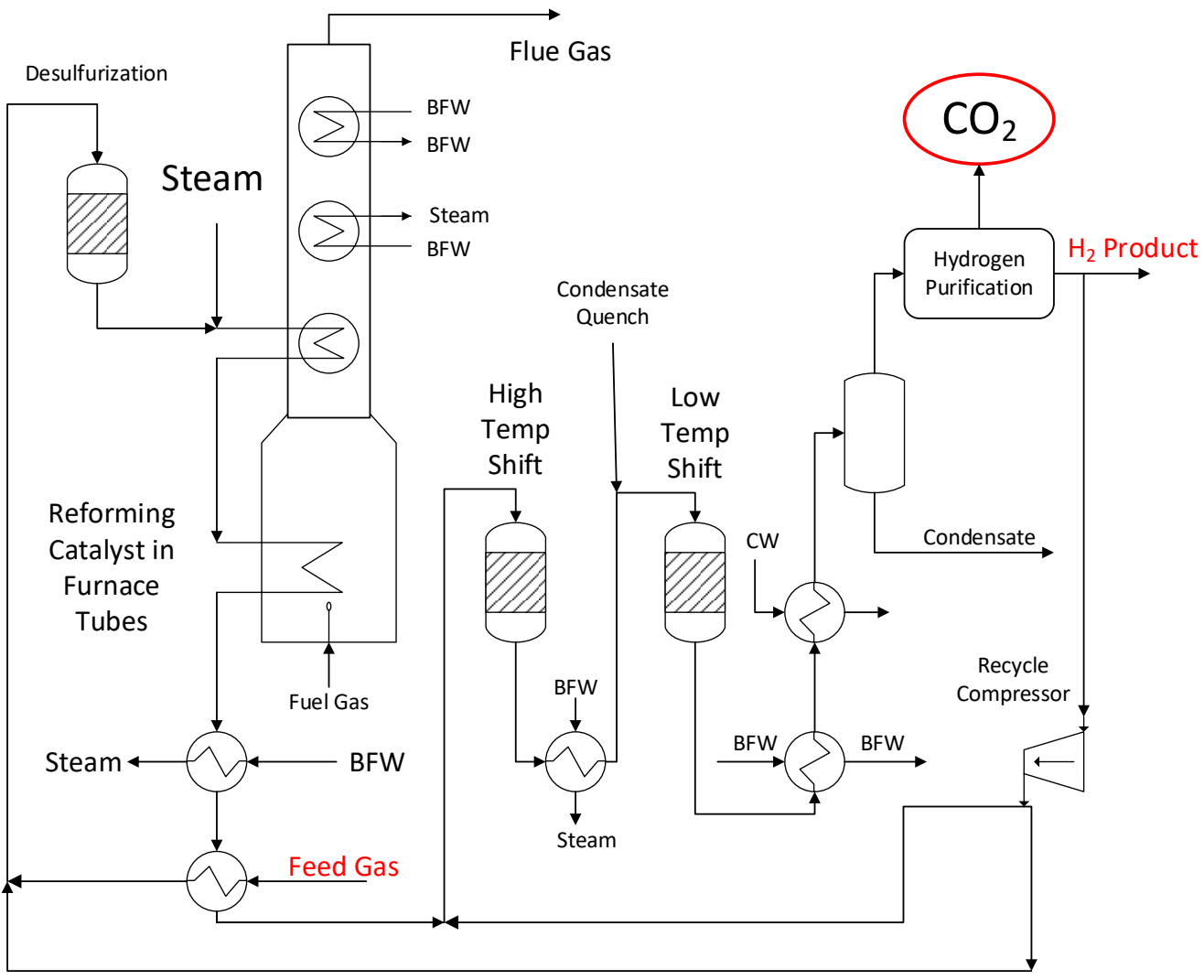

Fig SI12. Process Flow Diagram for a Hydrogen Plant $\mathrm{BFW}=$ Boiler Feed Water; $\mathrm{CW}=$ Cooling Water 


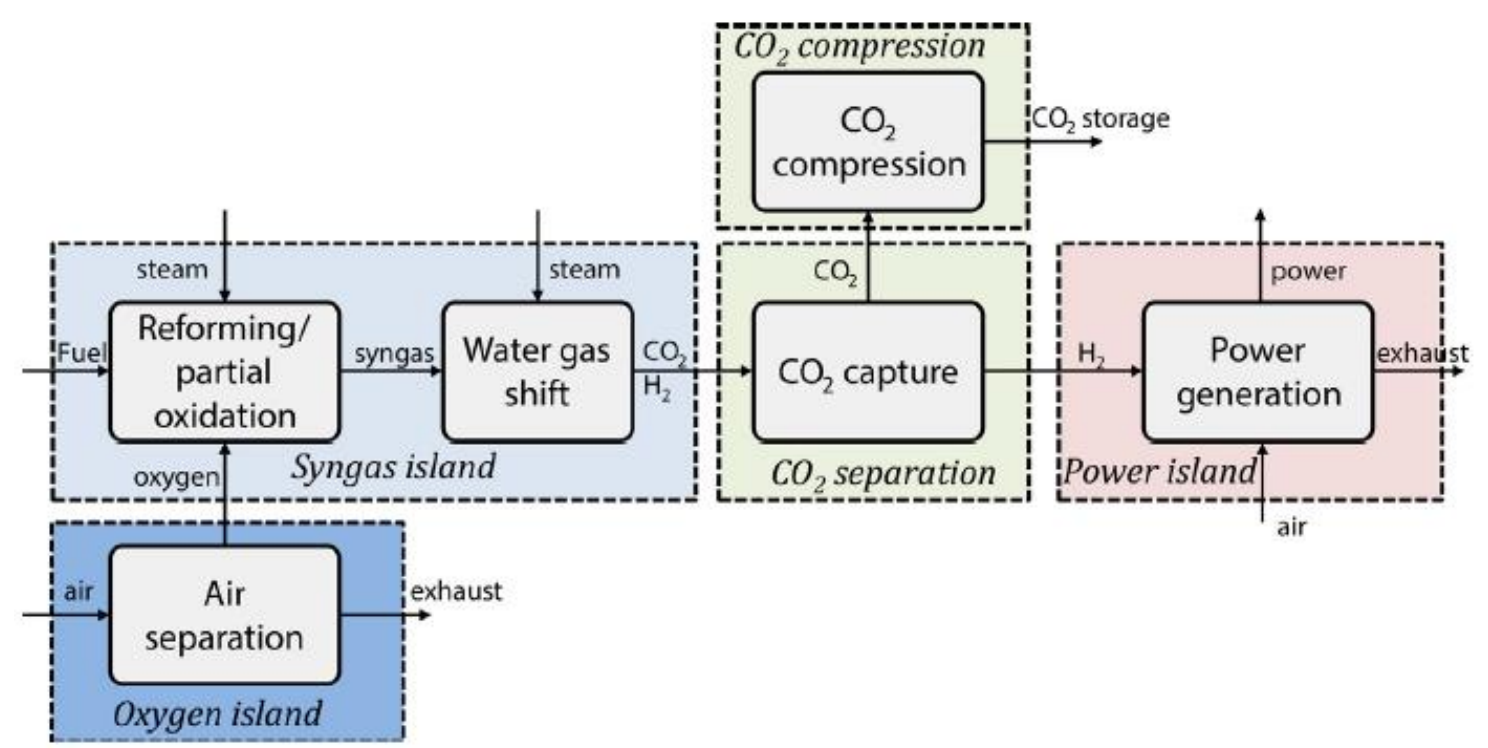

Fig. SI13. Oxy-Fuel Pre-Combustion Combined Cycle Power Plant

Source: Jansen, et al. (2015) [34]

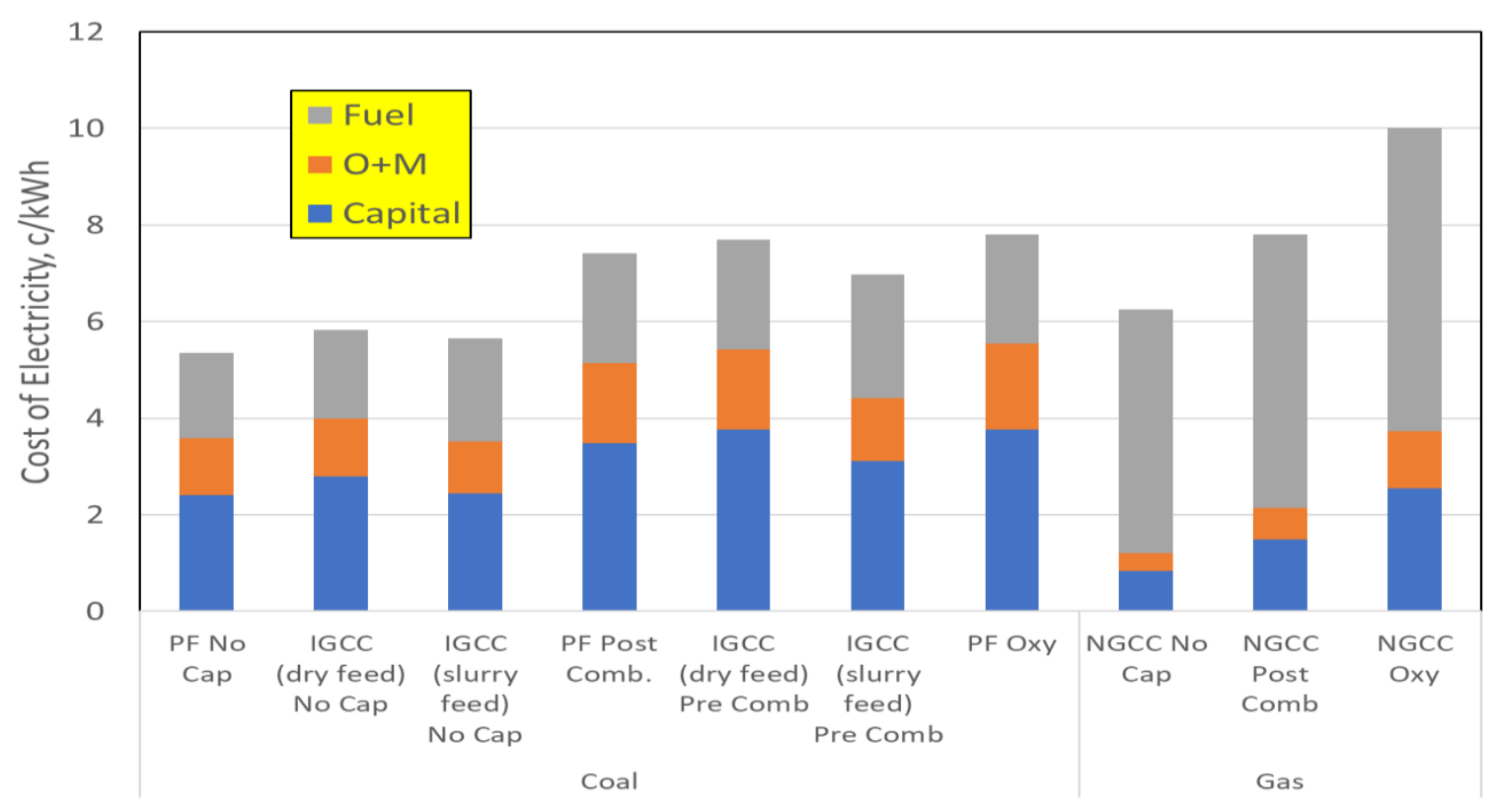

Fig. SI14. Projected Electricity Price With and Without $\mathrm{CO}_{2}$ Capture (Various Plant Configurations) Source: (IEA, 2017) All Rights Reserved. [36] 


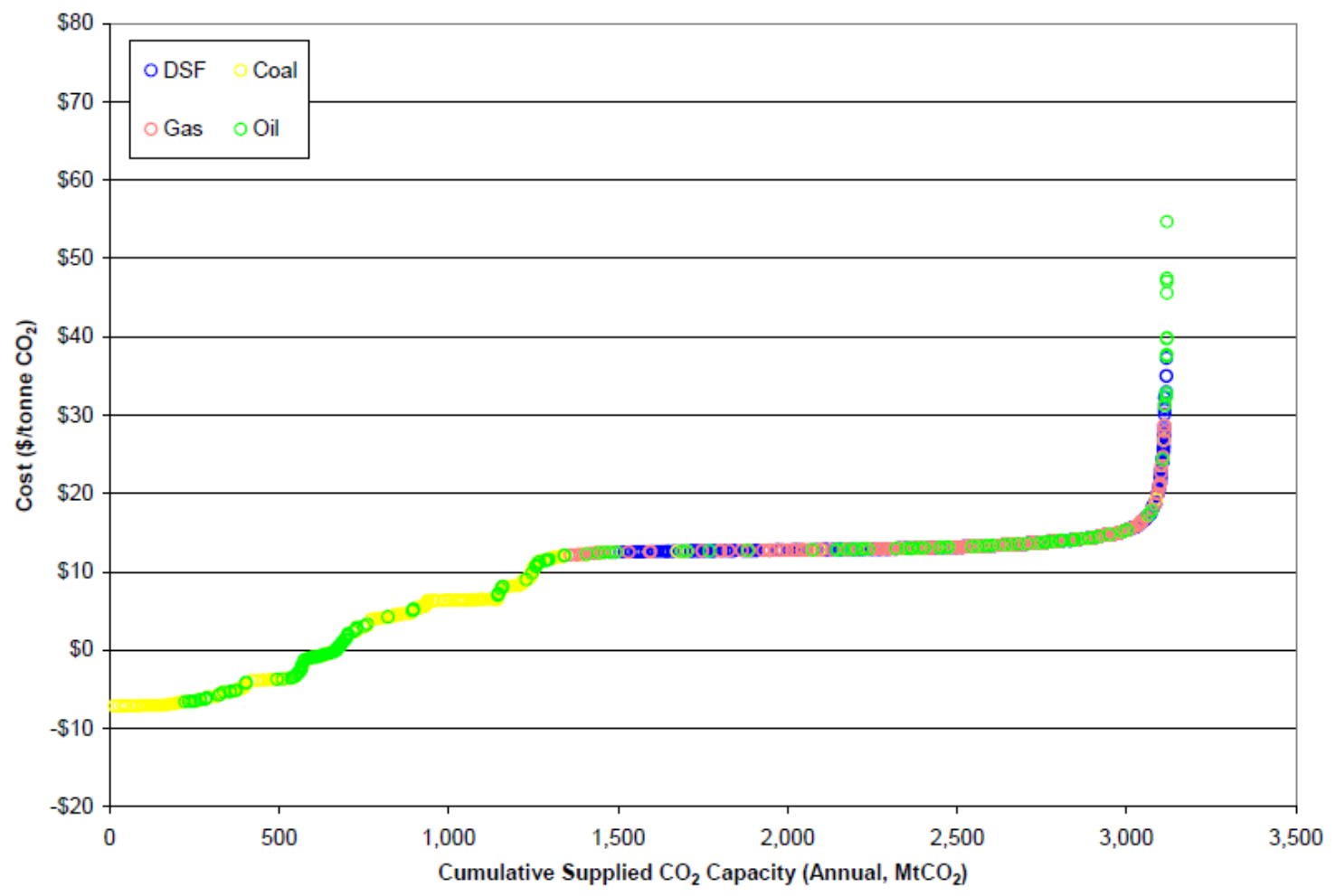

Fig. SI15. Projected Cost of $\mathrm{CO}_{2}$ Storage as a Function of Cumulative Amount Captured. Source: (IEA, 2017). All Rights Reserved. [36]

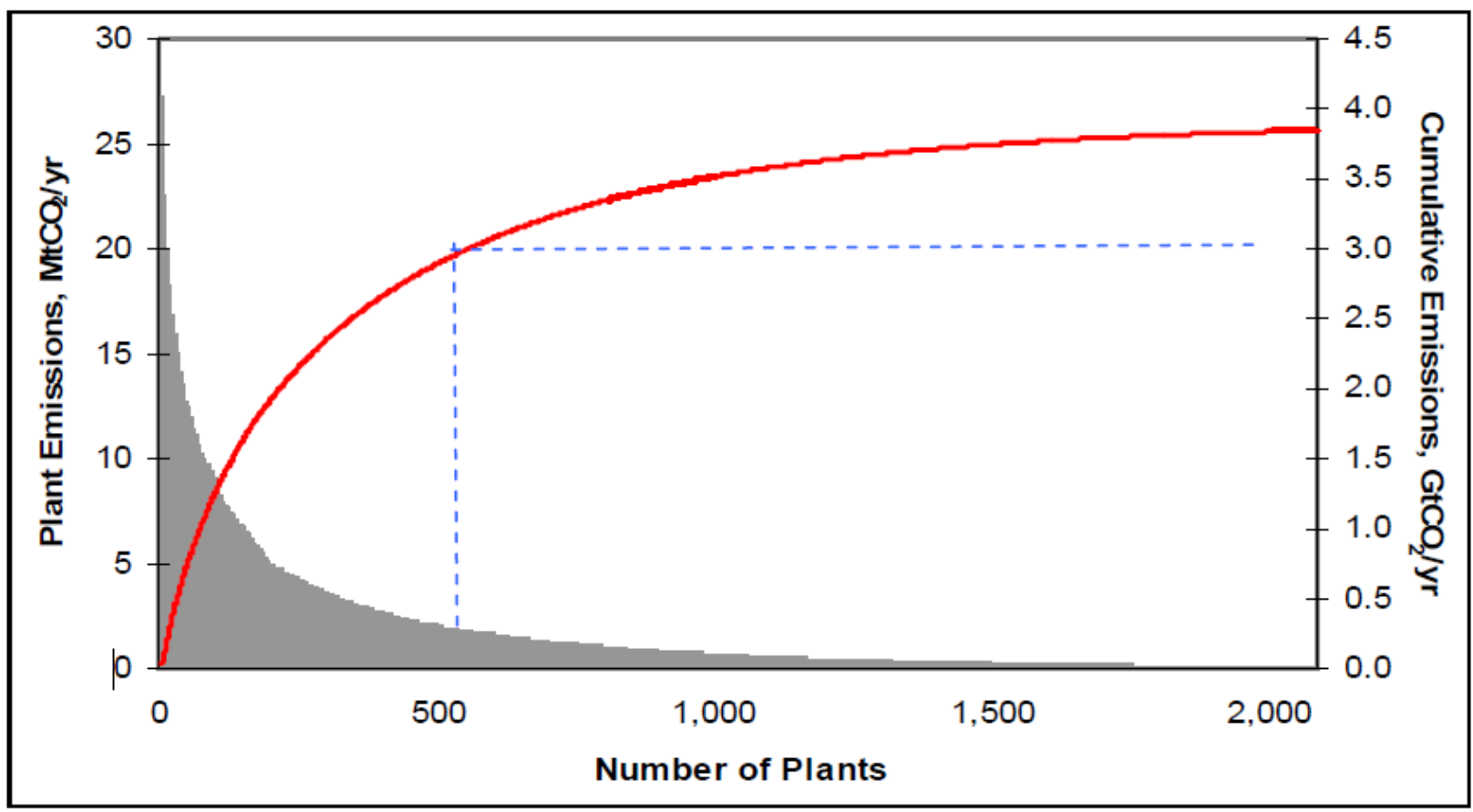

Fig. SI16 Cumulative CO2 Emissions Versus Cumulative Number of Point Sources Source: (IEA, 2005). All Rights Reserved. [35] 


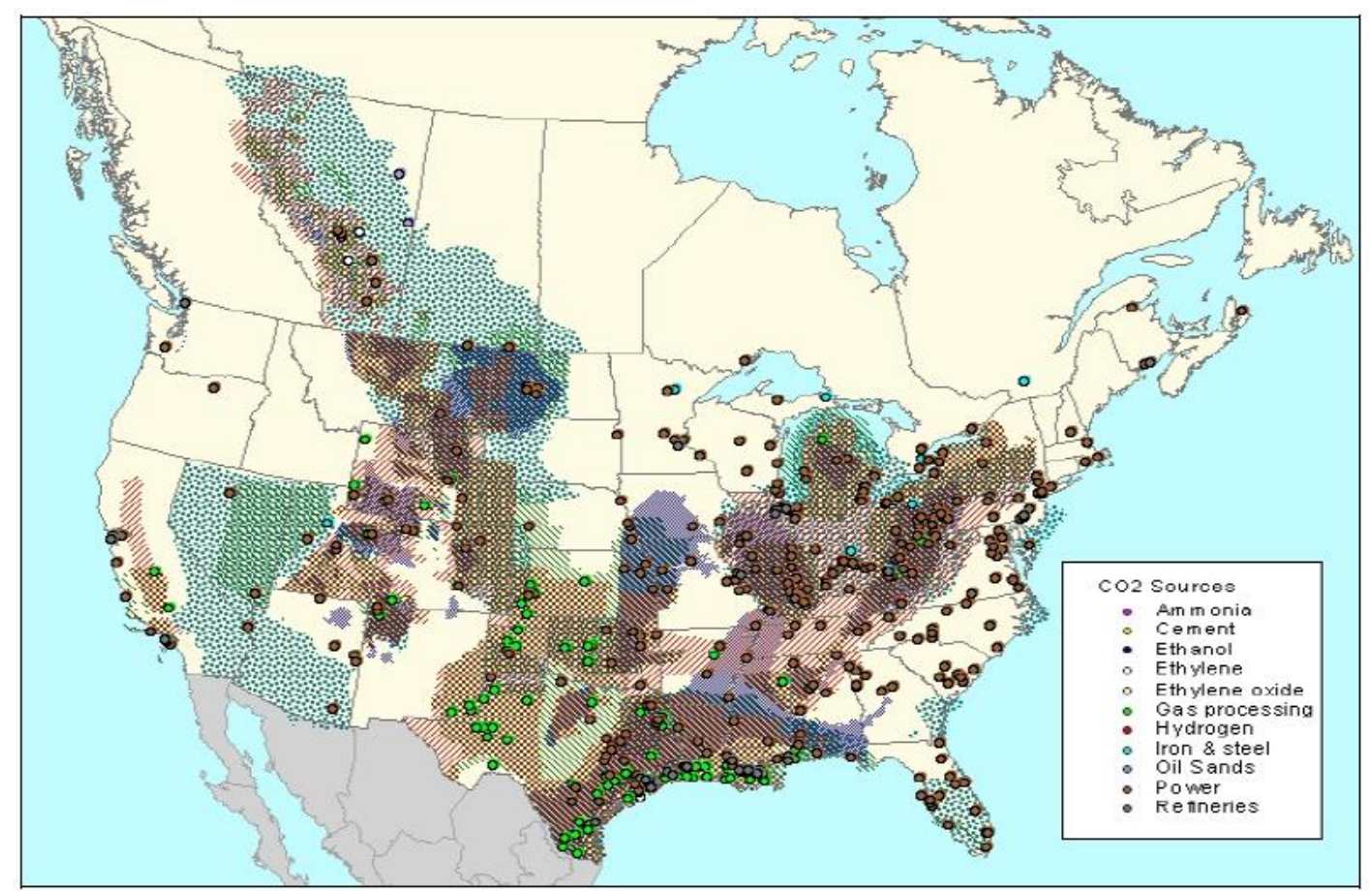

Fig. SI17. Overlap of 500 Largest Point Sources with Potential Locations for Storage Source: (IEA, 2005). All Rights Reserved. [35]

\section{Total MSW Landfill by Material, 2017}

\section{6 million tons}

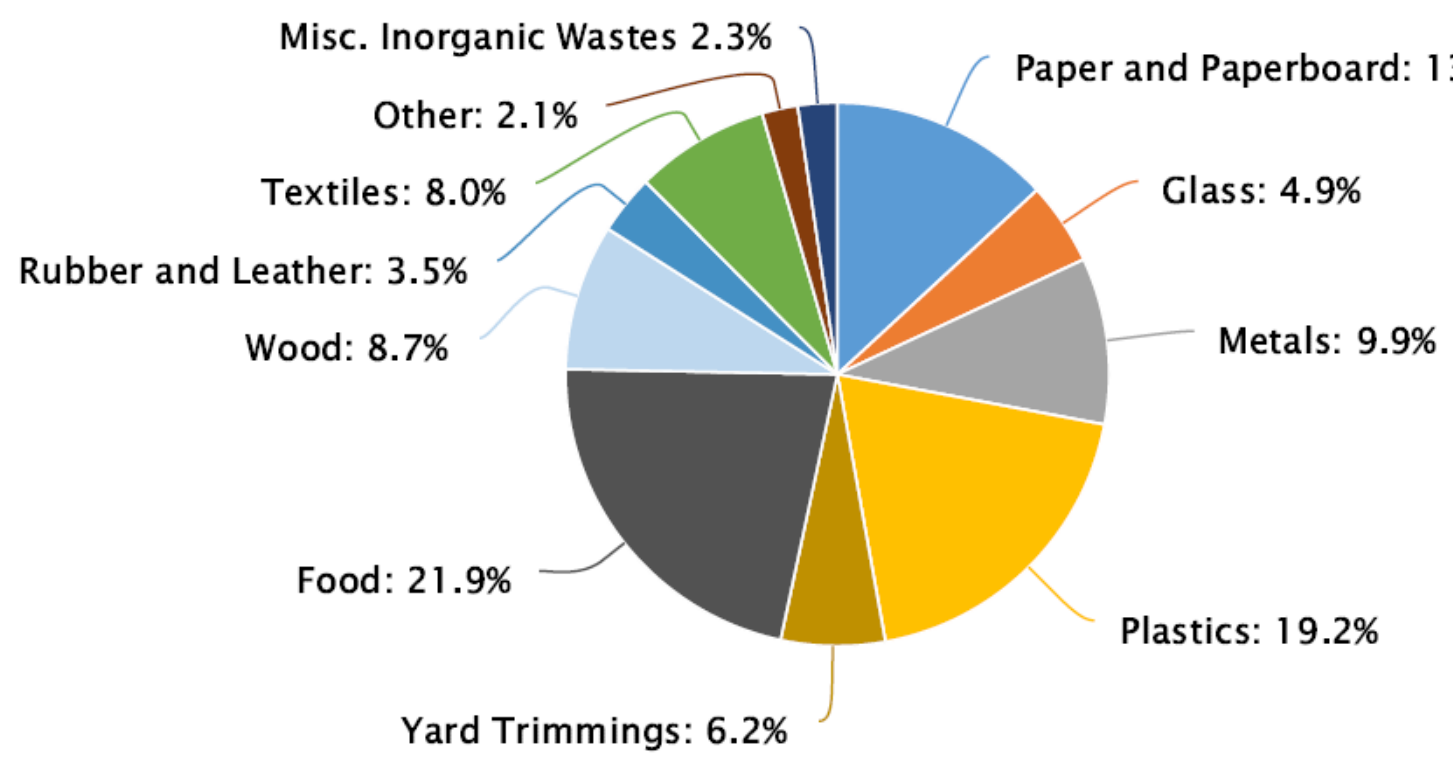

Fig. SI18. U.S. 2017 Municipal and Yard Waste Landfilled

Source: (EPA, 2020) [38]. 


\begin{tabular}{|c|c|c|c|c|c|c|c|c|}
\hline Oil or fat & 14:0 & $16: 0$ & 18:0 & $18: 1$ & $18: 2$ & $18: 3$ & $20: 0$ & 22:1 \\
\hline Soybean & & $6-10$ & $2-5$ & $20-30$ & $50-60$ & $5-11$ & & \\
\hline Corn & $1-2$ & $8-12$ & $2-5$ & $19-49$ & $34-62$ & & & \\
\hline HI Oleic Rapeseed & & 4.3 & 1.3 & 59.9 & 21.1 & 13.2 & & \\
\hline HI Erucic Rapeseed & & 3 & 0.8 & 13.1 & 14.1 & 9.7 & 7.4 & 50.7 \\
\hline $\begin{array}{l}\text { High Lineolic } \\
\text { Sunflower }\end{array}$ & & 5.9 & $12-18$ & 8.8 & 83.8 & & & \\
\hline HighOleic Sunflower & & 4.8 & 1.4 & 74.1 & 19.7 & & & \\
\hline Olive & & $9-10$ & $2-3$ & $73-84$ & $10-12$ & & & \\
\hline Lard & $1-2$ & $28-30$ & $12-18$ & $40-50$ & $7-13$ & $0-1$ & & \\
\hline Yellow Greese & 1.27 & 17.44 & 12.38 & 54.67 & 7.96 & 0.69 & & \\
\hline Peanut & & $8-9$ & $2-3$ & $50-65$ & $20-30$ & & & \\
\hline Cotton Seed & $0-2$ & $20-25$ & $1-2$ & $23-35$ & $40-50$ & & & \\
\hline Butter & $7-10$ & $24-26$ & $10-13$ & $28-31$ & $1-2.5$ & $0.2-0.5$ & & \\
\hline Tallow & $3-6$ & 24-32 & $20-25$ & $37-43$ & $2-3$ & & & \\
\hline Linseed Oil & & $4-7$ & $2-4$ & $25-40$ & $35-40$ & $25-60$ & & \\
\hline Tung Oil & & $3-4$ & $0-1$ & $4-15$ & & $75-90$ & & \\
\hline
\end{tabular}

Table S1. Side chain carbon number distribution of vegetable oils

Note: 18:2 means a side chain of 18 carbons with 2 double bonds, etc. 